\title{
Impact of the Great Recession on Retirement Trends in Industrialized Countries
}

\author{
Gary Burtless and Barry P. Bosworth \\ THE BROOKINGS INSTITUTION \\ Washington, D.C.
}

November 5, 2013

This research was supported by a grant from the U.S. Social Security Administration (SSA) as part of the Retirement Research Consortium (RRC). We are grateful to Mattan Alalouf of Brookings for excellent research assistance. The findings and conclusions expressed are solely those of the author and do not represent the views of the Brookings Institution, SSA, any agency of the Federal Government or the Retirement Research Center at Boston College. 


\title{
Impact of the Great Recession on Retirement Trends in Industrialized Countries
}

\author{
by \\ Gary Burtless and Barry Bosworth
}

\begin{abstract}
The Great Recession had a large impact on unemployment rates and growth in wealthy industrial countries. When the recession began most rich countries were experiencing an increase in labor force participation rates after age 60 . This paper examines whether the downturn slowed or reversed the trend toward higher old-age participation rates. We use straightforward time series analysis to test for a break in labor force trends after 2007. Our results indicate that the average rate of increase in labor force participation slowed in only a handful of countries. Averaging across all 20 countries in our sample, we find that the average pace of labor force participation increase was faster after 2007 than before. Countries that experienced unusually severe downturns represent exceptions to this generalization. In most countries, however, the trend toward later retirement not only continued, it accelerated.
\end{abstract}




\title{
Impact of the Great Recession on Retirement Trends in Industrialized Countries
}

\author{
by \\ Gary Burtless and Barry Bosworth \\ THE BROOKINGS INSTITUTION
}

LABOR FORCE PARTICIPATION among people past age 60 fell in nearly all rich countries in the half century after World War II. In recent decades, however, participation rates among the elderly have begun to recover in most of these same countries. With few exceptions wealthy countries saw a decline in old-age labor force exit compared with exit rates that were common before the mid-1990s. The drop in exit rates was hardly uniform across countries, but declines were visible in a large proportion of countries. In an analysis of labor force trends in 21 rich countries after 1960, Burtless (2008) estimated the low point of old-age male participation rates and the subsequent increase in participation rates that occurred after the low point was attained up through 2006. From the participation-rate low he found that average participation rates increased 9.1 percentage points among men 60-64 and rose 5.6 percentage points among men between 65 and 69. These estimates represent average increases in male participation in 21 industrialized countries through 2006. In comparison with the long-term decline in participation rates that occurred after 1960, the increases in male participation rates were not trivial. For men between 60 and 64 the increase offset about one-quarter of the earlier decline between 1960 and the trough year. The rise in the participation rates of older men and women differed widely across countries, and a handful of countries saw little increase. The evidence suggests, however, that rising old-age participation and employment rates were widespread throughout the industrialized world.

It is natural to ask whether the Great Recession slowed or reversed the trend toward later retirement. The recession had a large impact on unemployment rates and job availability in the United States and many other industrial countries. In April 2013, 48 million adults in Organisation for Economic Co-operation and Development (OECD) member countries were unemployed, an increase of 16 million, or about 50 percent, compared with the number of unemployed in 2007 (OECD 2013, 11). The sudden contraction of aggregate demand increased 
pressure on employers to dismiss workers. At the same time it reduced the number of new job openings, making it harder for laid-off older workers to find employment. On the other hand, the drop in household wealth after 2007, caused by declines in asset prices and prolonged spells of joblessness, may have induced some older workers to postpone retirement and encouraged others to return to the labor force. This paper examines whether the Great Recession and the weak recovery that followed have slowed or reversed the trend toward higher old-age participation and employment rates.

Using cross-nationally comparable data on labor force participation and employment-topopulation ratios within narrow age groups we estimate trends toward later retirement in 20 OECD member countries in the period from 1989 through 2012. We compare trends before and after 2007 to measure the effects of the Great Recession. Our results can be summarized briefly. Across the 20 countries we examine, the participation rate of 60-64 year-olds increased an average of 0.4 percentage points per year between 1989 and 2007. The participation rate of 6569 year-olds rose an average of 0.1 percentage points a year, and the participation rate of 70-74 year-olds increased at about half that rate. In all three older age groups the rate of gain in oldage participation rates was greater among women than among men. Notably, however, both sexes experienced statistically significant gains in participation, on average, over the period from 1989 through 2006.

We use straightforward time series analysis to test for a break in the trend toward higher labor force participation and employment after 2007. Our results indicate that the average rate of increase in labor force participation slowed in only a handful of countries after the onset of the Great Recession. In terms of labor force participation we found a significant slowing of the trend rate of change in just three of our 20 sample countries. All three-Greece, Portugal, and Ireland - experienced unusually severe recessions. The United States also experienced a significant slowdown in the rate of employment gain (though not participation rate gain) among 60-64 year-olds. Between 1989 and 2007 the employment rate of 60-64 year-old Americans increased at an average rate of 0.53 percentage points a year. Since 2007 it has risen just 0.17 percentage points a year. The slowdown is due to involuntary unemployment rather than withdrawal from the workforce, however. Interestingly, employment rates among Americans aged 65-69 and 70-74 continue to increase as fast as or faster than was the case between 1989 and 2007. 
Averaging across all 20 countries in our sample, the pace of labor force participation gains has accelerated since the onset of the Great Recession. As noted, the participation rate of 60-64 year-olds increased at an average rate of 0.4 percentage points a year between 1989 and 2007. Between 2007 and 2012 the participation rate in this age group increased an average of 1.5 percentage points a year. In 12 of the 20 countries, the increase in the trend rate of participation change was statistically significant. The participation rate of 65-69 year-olds increased at an average rate of 0.1 percentage points a year between 1989 and 2007. Since 2007 the participation rate in this age group has increased an average of 0.8 percentage points a year across the sample countries. In 13 of the 20 countries, the rise in the trend rate of participation gain was statistically significant. In the oldest age group, 70-74 year-olds, the trend rate of increase in participation rose from 0.05 percentage points a year between 1989 and 2007 to 0.32 percentage points a year after 2007. In 12 of the 19 sample countries the increase in the pace of participation gain among 70-74 year-olds was statistically significant.

Thus, the Great Recession slowed or reversed the trend toward later retirement in only a handful of rich countries, ones that suffered exceptionally severe downturns. For a majority of rich countries we find evidence that trend toward higher old-age participation rates picked up speed in the years after the onset of the recession. Longer life spans, improved health at older ages, and altered economic incentives for work in old age have contributed to the trends. It is striking, however, that a worldwide recession and historically weak labor markets did not derail the two-decade trend toward later retirement.

The remainder of the paper is organized as follows. The next section describes longer term trends in old-age labor force participation and workforce exit before the Great Recession. The following section describes our labor force data and statistical analyses of trends in participation and employment rates before and after the onset of the recession. The final section offers a summary of conclusions

\section{Labor force trends before the Great Recession}

A long-term trend toward earlier labor force exit came to an end in many industrialized countries between the end of the 1980 s and the early $21^{\text {st }}$ century. Old-age labor force participation rates, after declining for several decades, began to increase in a number of rich countries, including the United States. A variety of factors contributed to the reversal of U.S. 
retirement trends. One important factor was the change in public and private financial incentives for work in later life. In comparison with Social Security retirement benefits provided up through the mid-1980s, the current benefit formula provides stronger incentives for workers to postpone benefit claiming and smaller penalties on working while collecting a pension. Equally important, benefits are no longer increasing in relation to workers' lifetime earnings, a trend that boosted Social Security replacement rates between the 1960s and mid-1980s. The shift of the private retirement system from defined-benefit to defined-contribution pension plans has reduced incentives for workers to leave their pension-covered jobs when they are in their late 50s and early 60s. DB pensions ordinarily make it attractive for workers to leave their jobs at the early or standard retirement age in the plan. DC pensions only rarely provide this kind of inducement to leave work at a particular age. Finally, the high cost of obtaining health insurance outside of an employer health plan combined with the gradual disappearance of employer-provided retiree health benefits has increased the financial payoff to remaining employed in a job covered by employer-provided insurance. Other industrial countries besides the United States have adopted reforms in their public retirement systems to increase incentives for later retirement and to reduce penalties on work in later life. A number of countries have increased the benefit-claiming age, while others have adopted formulas for calculating pensions that offer bigger rewards for delaying exit from the workforce (Martin and Whitehouse 2008, pp. 8-14; OECD 2011).

The trends toward later retirement and higher participation rates in old age are most visible in the statistics for men. Figure 1 shows changes in male labor force participation rates within narrow 5-year age ranges in the United States and northern and southern Europe. The charts show percentage-point changes in each age group's participation rate between 1994 and 2007, the last year before the Great Recession. The data are drawn from the OECD labor force statistics file or, where data from that file are missing, from Eurostat's labor force statistics file. The statistics on northern Europe's participation rates reflect the unweighted average of rates for 10 countries: Austria, Belgium, Denmark, Finland, France, Germany, the Netherlands, Norway, Sweden, and the United Kingdom. The estimates for southern Europe are the unweighted average participation rates in Greece, Italy, Portugal, and Spain. In the period covered by the chart, 1994 to 2007, male participation rates remained nearly unchanged between ages 25 and 49, while younger men's participation rates fell noticeably in southern Europe and the United States. In northern Europe and the United States, however, we see a striking increase in 
participation rates after age 55. The gains were particularly large, both absolutely and relatively, among American men past 60 and among northern European men between 55 and 64. The trend toward later labor force exit was not universal. Participation rates among 60-74 year-old men in southern Europe changed very little between 1994 and 2007.

Participation trends among women show gains at all ages past 50 between 1994 and 2007 (Figure 2). The implication of the rising trend in older women's participation for the average age at retirement is not obvious, however, because participation rates of prime-age women rose impressively in earlier decades. Except in the United States and a few other countries which already had high female participation rates in the mid-1990s, the trend toward higher prime-age participation among women continued up to the Great Recession (see the middle and bottom panels in Figure 2). Thus, the participation rate of older women can increase over time, even if the average age at retirement among career workers is falling. In earlier analysis, Burtless (2008) showed that slower exit from the labor force explains some, though not all, of the increase in women's old-age participation rate. In fact, in most countries there was a striking similarity in the decline of old-age exit rates among men and women. The explanation is straightforward. Pension incentives, retirement norms, and institutions that influence career retirement patterns among men also affect retirement patterns among prime-age and older women. When these incentives, norms, and institutions change for working men, they tend to change in a similar direction for working women.

\section{Impact of the Great Recession}

The 2008-2009 financial crisis led to the deepest recession experienced by most OECD countries in several decades. Figure 3 shows annual measures of economic slack in the 20 countries examined in this paper. The 20 include 16 countries in western Europe-Austria, Belgium, Denmark, Finland, France, Germany, Greece, Ireland, Italy, the Netherlands, Norway, Portugal, Spain Sweden, Switzerland, and the United Kingdom_-plus four wealthy countries outside of Europe-Australia, Canada, Japan, and the United States. The period we examine is 1989-2012. The top panel shows the weighted percentage change in real GDP of the 20 countries. From 1989 through 2007 the growth rate averaged about 2.6 percent a year. Since 2007 it has averaged about 0.3 percent a year. Calendar years 2008 and 2009 are the only ones after 1988 with a negative average growth rate. Real GDP fell in half of the sample countries in 
2008 and in 19 of the 20 countries in 2009. For every country in our sample except Switzerland the IMF calculates potential GDP and the output gap between actual and potential GDP. After 2007 actual GDP shrank as a percentage of potential GDP in all 19 of those countries, and it fell by an average of about 5.9 percent of potential GDP.

The impacts on unemployment are displayed in Figure 4. The labor market effects of the Great Recession varied widely across countries. Between 2007 and 2009 the unemployment rate increased just 0.2 percent in the Netherlands and 0.4 percent in Austria and Belgium. The unemployment rate actually fell 0.9 percentage points in Germany. In those same years joblessness increased 9.8 percentage points in Spain, 7.5 points in Ireland, and 4.6 points in the United States. But whereas the unemployment effects of the recession have ebbed since 2009 in the United States and most other rich countries, data reported to the OECD show they have worsened in southern Europe and Ireland (see lower panel of Figure 4).

In spite of the severity of the recession we find little evidence of a sharp downward break in the trend of old-age labor force participation rates in the great majority of sample countries. Most countries with an upward trend in participation rates before the Great Recession continued to experience participation rate gains after 2007. Some countries with stable or declining old-age participation rates before 2007 saw an increase in participation rates after the onset of the recession. This pattern is evident in countries with high initial participation rates and in those where participation was initially well below the OECD average.

Figure 5 shows trends in labor force participation after 1989 within three older age groups. Results in the top panel show trends among men and women between 60 and 64 . The next two panels show the same trends among 65-69 and 70-74 year-olds, respectively. In each panel we separately tabulate trends within three groups of countries, those with high initial labor force participation rates in the age group, those with intermediate participation rates, and those with below average participation rates. ${ }^{1}$ Each line represents the unweighted average of participation rates in the indicated group of countries. A note at the bottom of the figure identifies the countries within each country grouping. In each case countries are classified according to their 1989 labor force participation rates in the indicated age group.

\footnotetext{
${ }^{1}$ Some of the 20 countries in our sample lack data for one of more years between 1989 and 2012 for one or more older age groups. In order to display estimates for a fixed sample of countries we dropped Austria, Ireland, and Switzerland from all of the panels in Figure 5. In addition we dropped Australia, Italy, and Japan from the panel showing participation rate trends among 70-74 year-olds.
} 
The top panel in Figure 5 shows participation rate trends among 60-64 year-old men and women. Both absolutely and proportionately the 1989-2012 increase in participation rates was greatest in the countries with low initial participation rates. The increase was smallest in the countries with high initial participation rates. In no country grouping, however, is there a noticeable break in the trend after 2007. In the second panel, which reflects trends among 65-69 year-olds, we also see little evidence of a break in the trend after 2007. The biggest upward trend in participation rates in this age group occurred in countries which initially had intermediate participation rates. Between 1989 and 2012 the average participation rate of 65-69 year-olds in this group of countries doubled, increasing from 10 percent to 20 percent of the 6569 year-old population. Over the same time span, countries with initially low 65-69 year-old participation rates saw an increase of only about 4 percentage points. Participation rates in countries with the highest initial participation rates remained approximately unchanged. The bottom panel shows trends in average participation rates among 70-74 year-olds. There were gains in participation rates in all three groups of countries, but little noticeable break in the trends after the onset of the Great Recession.

Break in participation trends. A more formal statistical analysis confirms the impression conveyed by Figure 5. To estimate the trend in labor force participation and the deviation in the trend after 2007, we estimated a simple time series regression of the form

(1) $L=\alpha+\beta(y-1989)+\delta \max (0, y-2007)$,

where $L_{y}=$ Labor force participation rate in year, $y$,

$\beta=$ Trend in labor force participation between 1989 and 2007; and

$\delta=$ Deviation in the time trend after 2007.

The regression was estimated separately for each gender, country, and older age group within a country.

Results for the 60-64 year-old population are reported in Table 1. The panel on the left shows results for 60-64 year-old men; the panel on the right displays results for women. Countries are listed by the estimated rate of increase in the participation rate between 1989 and 2007. ${ }^{2}$ Each row in the table shows the critical results for a given country. Hypothesis test

${ }^{2}$ As observed in note 1 , a few of the countries in the sample lack data for one of more years between 1989 and 2012. The countries lacking some data are included in the table if they report enough 
results are indicated by asterisks. The majority of estimates of the 1989-2007 time trend, $\beta$, are positive. In the case of men, 14 of the 20 countries have a positive trend through 2007 , and in 11 cases the positive trend is statistically different from zero at the 5 percent level. In only three countries, Portugal, Italy, and Switzerland, was there a statistically significant negative trend in male participation. Not surprisingly, the results for women are even more overwhelming in showing a trend increase in participation. All 20 countries are found to have a positive participation rate trend, and in 15 countries the positive trend is significantly different from zero.

The third column of results in both panels shows the estimated deviation, $\delta$, in the trend change in participation rates after 2007. The great majority of the estimates of $\delta$ are positive, indicating that for most countries the trend increase in participation rates after 2007 was greater than it was before 2007. For 60-64 year-old men the deviation estimates are positive in 16 of the 20 countries, and in 10 of these 16 countries the positive estimates are significantly different from zero. Three countries - Japan, Italy, and Switzerland-saw a reversal in the downward trend of male participation between 1989 and 2007. In four countries, however, the estimated deviation is negative, and in three of these the negative deviation is significantly different from zero. All of the countries with negative deviations - Greece, Ireland, Portugal, and Spainexperienced economic downturns after 2007 that were exceptional in both severity and persistence. Among women between 60 and 64 the upward trend in participation rates accelerated in 17 out of 20 countries. In 13 of these 17 countries the estimated deviation is significantly different from zero. The three countries that experienced a slowdown in the trend toward higher participation rates are Greece, Ireland, and Portugal, though only in Portugal was the slowdown significantly different from zero. Thus, both among men and women in the 60-64 year-old age group the trend increase in participation rates after 2007 was in most countries faster than in the period between 1989 and 2007.

The line at the bottom of Table 1 shows the unweighted average of the coefficients for the countries listed above. Though the experience of individual countries varied widely over the estimation period, the average of trends across the countries shows a picture of generally increasing participation rates, both before and after 2007. On average, the participation rate of 60-64 year-old men increased 0.19 percentage points a year and that of 60-64 year-old women

information so that we can estimate the trend changes in participation rates before and after 2007. Australia is excluded from the estimates for 70-74 year-olds because we could not find published data on this Australian age group. 
increased 0.55 percentage points a year during the period between 1989 and 2007. After 2007 the annual rate of increase accelerated to 1.34 percentage points in the case of men and to 1.61 percentage points in the case of women. Thus, on average participation rates among 60-64 yearolds were increasing before 2007, and the rate of increase accelerated after the onset of the Great Recession. Before 2007 participation rates among women in this age group were rising faster than participation rates among men. In half the countries, the gains among women were significantly faster than they were among men the same age. However, the acceleration in participation rates after 2007 was similar among men and women for most countries. In only three of the 20 countries did we find a significant difference in the acceleration of male and female participation rates after 2007.

Figure 6 shows the close relationship between participation rate trends for men and women in the same countries. The data refer to our estimates of annual participation rate changes after 2007. Results in the top panel show the correlation of participation rate changes among men and women who are between 60 and 64 years old. Participation rate changes among men in the age group are indicated on the $\mathrm{X}$-axis, while participation rate changes among women are indicated by the Y-axis. Countries, such as Germany and the Netherlands, that experienced sizeable increases in the participation rate of 60-64 year-old men also saw proportionately large jumps in the participation rates of women the same age. Countries that experienced small or negative changes in male participation on average experienced smaller changes in female participation rates. The correlation of men's and women's participation rate changes is 0.85 . The high correlation can be explained by the common factors, such as shifts in pension policy and fluctuations in aggregate demand, that affect both sexes in a given age group. However, the correlation between men's and women's participation rate changes was considerably higher after 2007 than it was between 1989 and 2007.

Table 2 shows estimates of labor force participation trends among 65-69 year-old men and women. Between 1989 and 2007 nearly half of sample countries saw a trend decline in participation rates in this age group. In six countries there was a statistically significant decline among men, and in the same number of countries there was a significant decline among women. On balance, however, the countries that saw participation rate increases outnumbered those where participation rates tended to decline. In eight countries the positive trend in male and female participation rates was statistically significant. More notable is the upward shift in 
participation rate trends that occurred after 2007. The estimate of $\delta$ is positive for men in all but three of the countries. It is positive for women in all but one of the countries. Moreover, most of the positive estimates of $\delta$ are significantly different from zero at the 5 percent level. For men the deviation term is positive and significantly different from zero in 11 countries and negative and significantly different from zero in just one country. For women the pattern is the same: The deviation term, $\delta$, is positive and significantly different from zero in 14 countries and negative and significantly different from zero in just one. Averaged across all 20 countries the participation rate in the 65-69 year-old group tended to rise very slowly between 1989 and 2007 but at a considerably faster pace after 2007 (see the bottom row in Table 2). In the years after 2007 the male participation rate increased in 17 out of 20 countries (all but Greece, Ireland, and Portugal) and the female participation rate rose in 19 out of 20 countries (all but Portugal).

The middle panel of Figure 6 shows the correlation between men's and women's participation rate changes across the 20 countries. We see a strong statistical association between participation rate changes experienced by men and women in the same country. Australia, Canada, and Norway saw exceptionally rapid annual gains in 65-69 year-old male participation after 2007. These same countries also experienced faster-than-average increases in 65-69 year-old female participation. Greece, Ireland, Portugal, and Spain saw little change or sizeable drops in male participation among 65-69 year-olds. These same countries experienced below average gains in participation among 65-69 year-old women. The correlation of male and female participation rate changes across the 20 countries is 0.87 .

We find relatively modest shifts in the participation rates of people between 70 and 74 over the 1989-2007 period (Table 3). Male labor force participation in this age group was trending upward in about half the countries in our sample, and female participation was increasing in about three-quarters of the countries. The estimated trends were significantly different from zero in about half the countries, both for men and for women. Estimates of the deviation term, $\delta$, show the same pattern found for the two younger age groups. Most countries experienced a faster trend increase in participation rates after 2007 compared with the 1989-2007 period. The estimated deviation term, $\delta$, is negative in only two of 19 countries in the case of 7074 year-old men, and it is negative in only two of 19 countries for 70-74 year-old women. About half the estimated values of $\delta$ are positive and significantly different from zero. In only one country, Portugal, is a negative estimate of $\delta$ significantly different from zero. Averaging the 
results across all 19 countries, we find a sizeable jump in the pace of participation gain after 2007 compared with the period before (see bottom row in Table 3). Before 2007 the participation rate of 70-74 year-old men was increasing at an average rate of 0.02 percentage points per year. After 2007 the rate of increase jumped to 0.38 points a year. The comparable estimates for 70-74 year-old women were +0.06 percentage points a year before 2007 and +0.24 points a year after 2007. Although the average rates of gain after 2007 may seem small, they are not trivial when measured against participation rates that are typical in this age group. In 2002, for example, the 19-country average participation rate of 70-74 year-old men was 9.5 percent and the average participation rate among 70-74 year-old women was just 4.0 percent. The bottom panel of Figure 6 shows the correlation between 70-74 year-old men's and women's participation rate changes across the 19 countries in this sample. Again there is a strong association between participation rate changes experienced by men and women in the same country. The association is a bit weaker in the 70-74 year-old population than it is in the two younger age groups. The correlation of male and female participation rate changes is 74 percent.

The implicit assumption of the specification estimated in Tables $1-3$ is that the deviation in the participation rate trend after 2007 can be measured relative to the trend in labor force participation over the period from 1989 through 2007. In Figure 5 it is plain, however, that there may have been breaks in labor force participation trends between 1989 and 2007. In particular, a number of countries experienced declines in old-age labor force participation after 1989 that were followed by trend increases in participation in the years immediately before 2007 . As a sensitivity test we re-estimated equation (1) with data starting in 1994 rather than 1989. Results from the re-estimation are presented in an appendix. In brief they show a stronger upward trend in labor force participation rates in the period before 2007 than are estimated in Tables $1-3$ and a smaller positive deviation in the trend after 2007. Nonetheless, the results of the alternative specification also show positive deviations for a majority of countries and a continuation in the upward trend in old-age labor force participation after the Great Recession. On average across the 20 countries the trend toward later retirement accelerated after 2007 compared with the trend between 1994 and 2007.

Impact of unemployment. Though most countries saw a continued upward trend in oldage participation rates after 2007, in a handful of countries there was a break in this trend for one or more of the older age groups we have examined. In many cases countries with a negative 
deviation in participation trends were severely affected by the Great Recession, experiencing sizeable increases in unemployment over a sustained period. We have derived estimates of changes in labor market slack using OECD estimates of national unemployment rates in the 1564 year-old population. Our estimate of the change in labor market slack is the increase in the national unemployment rate between 2005-2007 and 2012. Figure 7 shows the relationship between overall labor market slack and the estimated deviation of the old-age labor force participation rate trend before and after $2007 .^{3}$ The change in the unemployment rate between 2005-2007 and 2012 is indicated on the horizontal axis. The deviation in the participation rate trend for the combined male and female population is indicated on the vertical axis. The top panel in the chart shows the relationship between labor force trend changes and unemployment changes in the population between 60 and 64. The lower panel shows results for the population age 65-69. Countries with little change in their unemployment rates clearly experienced bigger positive deviations in their old-age labor force participation trends. Countries with exceptionally large and persistent increases in unemployment tended to experience negligible or negative deviations in their previous old-age participation trends. The regression lines are obviously influenced heavily by the experiences of Greece, Ireland, Portugal, and Spain, which saw the biggest sustained increases unemployment. Results for the 70-74 year-old population, not shown in the chart, follow the same pattern observed for the two younger age groups. However, the inverse correlation between trend deviations in the participation rate and increases in the unemployment rate is somewhat weaker in the oldest population.

The effect of high unemployment on old-age labor supply should also be visible in the employment-to-population ratio of older age groups. Figures $8 \mathrm{a}$ and $8 \mathrm{~b}$ shows changes in the employment-population ratio in selected age groups between 2007, the last pre-recession year, and 2012. The bars in the chart indicate employment-to-population rates in 2007, while the diamonds show employment rates in 2012. Countries are ranked by their employment-topopulation ratios for a given age group in 2007. The top panel in Figure 8a shows gainful employment rates in the population between 25 and 54. Because prime-age adults have a high likelihood of participating in the workforce, we should expect that a jump in the unemployment rate will be quickly reflected in a drop in the prime-age employment-to-population ratio. This

\footnotetext{
${ }^{3}$ The estimated deviations reflect the difference between the old-age labor force trend between 1989 and 2007 and the trend after 2007. To simplify the graphical presentation, we only use results based on the combined population of men and women in a given age group (regression results not shown).
} 
expectation is borne out in the chart. All but four of the 20 countries in our sample experienced reductions in prime-age employment rates. Southern European countries and Ireland saw the biggest drops, though the United States and Denmark also experienced notable employment reductions in this age group. In contrast, Austria, Switzerland, and especially Germany experienced gains in prime-age employment. Japan's prime-age employment rate remained approximately unchanged.

The lower panel in Figure 8a shows trends in the employment-to-population rate of 60-64 year-olds. Perhaps surprisingly, employment rates in this older population increased in all but four countries (Greece, Ireland, Portugal, and Spain). In the other 16 countries the employment rate of 60-64 year-olds increased an average of 4.8 percentage points between 2007 and 2012. In spite of the labor market weakness reflected in shrunken employment-to-population rates in the prime-age population, employment among 60-64 year-olds continued to edge up. Results for the 65-69 and 70-74 year-old populations show a similar pattern (Figure 8b). Only a handful of countries experienced an actual decline in old-age participation rates, and all of the countries experiencing a decline suffered an exceptionally severe and prolonged recession. In the 65-69 year-old age the employment-to-population rate increased in 15 of the 19 countries for which we have data. Only Greece, Ireland, Portugal, and Spain saw a drop in employment rates in this age group. The 15 countries that saw an increase in the 65-69 year-old employment rate experienced an average gain of 3.0 percentage points between 2007 and 2012. For purposes of comparison, the average 2007 employment-to-population ratio in these 15 countries was 14.4 percent. Thus, the rise in employment between 2007 and 2012 pushed up the employment-to-population ratio in this age group by about one-fifth. Eighteen countries supply information on the 2007 and 2012 employment-to-population of 70-74 year-olds. Of these, employment rates among 70-74 yearolds increased in 15 countries (all except Greece, Portugal, and Spain). Between 2007 and 2012 the average employment rate gain of countries experiencing a gain in employment was 1.1 percentage points, or about one-sixth of the average employment-to-population ratio among 7074 year-olds in 2007.

Figures $8 \mathrm{a}$ and $8 \mathrm{~b}$ clearly show that employment rates among the aged vary widely across industrial countries, much more widely than employment rates in the 25-54 year-old population. ${ }^{4}$

\footnotetext{
${ }^{4}$ Employment rate changes in the prime-age and older population over the full 1989-2012 period covered by our analysis are displayed in appendix Figures A1 and A2. Because 1989 employment-rate
} 
The evidence also suggests that old-age employment rates continued to increase in most wealthy countries in the years after the onset of the Great Recession. In statistical analysis not shown here we estimated employment time trends after 1989 and 1994 and deviations in employment time trends after 2007 among older age groups. The estimates show a pattern that is broadly similar to the one we found for old-age labor force participation rates. In general, most countries in our sample experienced increasing old-age employment rates in the years immediately before the Great Recession. Most countries that experienced a break in the upward trend of old-age employment after 2007 saw employment rates increase faster after 2007. Countries that saw a slowdown in employment gains among the aged were ones that experienced unusually severe and prolonged recessions. For the great majority of rich countries the trend toward higher oldage labor force participation and employment rates has survived the Great Recession.

\section{Conclusions}

Averaging across all 20 countries in our sample, we find that the pace of labor force participation gains typically accelerated after the onset of the Great Recession. In the combined population of men and women, the participation rate of 60-64 year-olds increased at an average rate of 0.4 percentage points a year between 1989 and 2007. Between 2007 and 2012 the participation rate in this age group increased an average of 1.5 percentage points a year. In 12 of the 20 wealthy countries in our sample, the increase in the trend rate of participation change was statistically significant. The participation rate of the combined population of 65-69 year-old men and women increased at an average rate of 0.1 percentage points a year between 1989 and 2007. Since 2007 the participation rate in this age group has increased an average of 0.8 percentage points a year across the sample countries. In 13 of the 20 countries, the rise in the trend rate of participation gain was statistically significant. In the oldest age group we examine, 70-74 yearolds, the trend rate of increase in participation rose from 0.05 percentage points a year between 1989 and 2007 to 0.32 percentage points a year after 2007. In 12 of the 19 sample countries the increase in the pace of participation gain among 70-74 year-olds was statistically significant. Even if we shorten the analysis period to exclude the period between 1989 and 1993, when oldage participation rates were declining in some countries, we find the same general pattern

data are missing for some countries, the appendix does not contain estimates for all of the countries included in Figures 8a and 8b. 
uncovered in our basic analysis: The rate of increase in old-age labor force participation was on average higher after 2007 than before. Countries that experienced unusually severe downturns, including Ireland and much of southern Europe, represent exceptions to this generalization. On the whole, however, the trend toward later retirement in rich countries has not been reversed as a result of the Great Recession. 


\section{References}

Burtless, Gary. 2008. "The Rising Age at Retirement in Industrial Countries." Working Paper No. 2008-6. (Chestnut Hill, MA: Center for Retirement Research at Boston College).

Martin, John, and Edward Whitehouse. 2008. "Reforming Retirement-income Systems: Lessons from the Recent Experiences of OECD Countries." (Paris: OECD).

Organisation of Economic Co-operation and Development. 2011. Pensions at a Glance 2011: Retirement-income Systems in OECD and G20 Countries. (Paris: OECD). . 2013. OECD Employment Outlook 2013. (Paris: OECD). 
Table 1. Regression Estimates of Labor Force Participation Trends before and after 2007 in Twenty OECD Countries: Men and Women Aged 60-64

\begin{tabular}{|c|c|c|c|c|c|c|c|c|c|c|c|}
\hline \multicolumn{6}{|c|}{$\begin{array}{l}\text { Dependent variable: } \\
\text { Labor force participation rate of } 60-64 \text { year-old men in the } \\
\text { indicated country, } 1989-2012\end{array}$} & \multicolumn{6}{|c|}{$\begin{array}{l}\text { Dependent variable: } \\
\text { Labor force participation rate of } 60-64 \text { year-old women in } \\
\text { the indicated country, } 1989-2012\end{array}$} \\
\hline \multirow{2}{*}{$\begin{array}{l}\text { Country } \\
\text { Netherlands }\end{array}$} & \multirow{2}{*}{$\begin{array}{r}\text { Constant } \\
17.8\end{array}$} & \multicolumn{2}{|c|}{ Trend } & \multicolumn{2}{|c|}{ Post-2007 Trend } & \multirow{2}{*}{ 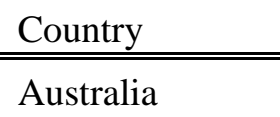 } & \multirow{2}{*}{$\begin{array}{r}\text { Constant } \\
10.9\end{array}$} & \multicolumn{2}{|c|}{ Trend } & \multicolumn{2}{|c|}{ Post-2007 Trend } \\
\hline & & 0.96 & $* * *$ & 3.60 & $* * *$ & & & 1.21 & $* * *$ & 1.66 & $* * *$ \\
\hline Finland & 22.7 & 0.79 & $* * *$ & 1.57 & $*$ & Ireland & 9.1 & 1.14 & $* * *$ & -0.01 & \\
\hline Germany & 27.0 & 0.69 & $* * *$ & 3.63 & $* * *$ & Finland & 15.3 & 0.95 & $* * *$ & 1.86 & $* *$ \\
\hline Austria & 11.2 & 0.67 & $* * *$ & 1.03 & & Canada & 19.8 & 0.92 & $* * *$ & 1.32 & $* *$ \\
\hline Ireland & 51.5 & 0.36 & $* * *$ & -1.01 & $* *$ & Germany & 6.1 & 0.92 & $* * *$ & 3.12 & $* * *$ \\
\hline Canada & 45.5 & 0.36 & $* * *$ & 1.19 & $*$ & Portugal & 24.4 & 0.81 & $* * *$ & -1.85 & $* * *$ \\
\hline Australia & 46.6 & 0.34 & $* * *$ & 2.07 & $* * *$ & Switzerland & 28.4 & 0.78 & $* * *$ & 0.80 & $*$ \\
\hline Sweden & 58.3 & 0.30 & $* *$ & 1.80 & $* *$ & Netherlands & 4.6 & 0.78 & $* * *$ & 2.79 & $* * *$ \\
\hline United States & 53.2 & 0.29 & $* * *$ & 0.18 & & United States & 33.8 & 0.75 & $* * *$ & 0.05 & \\
\hline United Kingdom & 50.9 & 0.24 & $* *$ & 0.71 & & United Kingdom & 21.8 & 0.55 & $* * *$ & 0.49 & $*$ \\
\hline Belgium & 18.0 & 0.21 & $* * *$ & 1.08 & $* * *$ & Norway & 44.9 & 0.45 & $* * *$ & 0.46 & $* *$ \\
\hline Spain & 43.5 & 0.21 & $*$ & -0.32 & & Sweden & 48.0 & 0.45 & $* * *$ & 0.99 & \\
\hline France & 13.5 & 0.04 & & 2.13 & $* * *$ & Belgium & 2.8 & 0.39 & $* * *$ & 1.17 & $* * *$ \\
\hline Norway & 62.7 & 0.01 & & 0.73 & $* *$ & Spain & 14.1 & 0.35 & $* * *$ & 1.86 & $* * *$ \\
\hline Denmark & 47.0 & -0.05 & & 1.45 & $*$ & Denmark & 24.4 & 0.19 & & 1.89 & $* * *$ \\
\hline Japan & 74.3 & -0.10 & & 1.00 & $* * *$ & Greece & 18.4 & 0.14 & $* * *$ & -0.42 & $*$ \\
\hline Greece & 46.7 & -0.11 & $*$ & -0.89 & $* * *$ & Austria & 7.5 & 0.12 & & 1.19 & $* * *$ \\
\hline Portugal & 55.9 & -0.23 & $* * *$ & -0.70 & $* *$ & France & 11.2 & 0.08 & & 1.52 & $* * *$ \\
\hline Italy & 34.8 & -0.33 & $* * *$ & 0.97 & $* * *$ & Japan & 39.4 & 0.07 & $*$ & 1.25 & $* * *$ \\
\hline Switzerland & 77.0 & -0.77 & $* * *$ & 2.71 & $* * *$ & Italy & 8.8 & 0.04 & & 1.09 & $* * *$ \\
\hline Average & 42.9 & 0.19 & & 1.15 & & Average & 19.7 & 0.55 & & 1.06 & \\
\hline
\end{tabular}

Notes: The estimation equation for each country is: $L=\alpha+\beta(y-1989)+\delta(y-2007)$, where $y$ is the calendar year, $L_{y}$ is the labor force participation rate in year $y, \beta$ is the coefficient on calendar year, and $\delta$ is the deviation in the time trend effect after 2007. Estimates were obtained using data for 1989-2012. Asterisks indicate statistical significance under a two-tailed t-test ( $* * *$ indicates $P<0.01, * *$ indicates $P<0.05$, and $*$ indicates $P<0.10$ ). Countries are ranked by the rate of participation-rate gain through 2007. 
Table 2. Regression Estimates of Labor Force Participation Trends before and after 2007 in Twenty OECD Countries: Men and Women Aged 65-69

\begin{tabular}{|c|c|c|c|c|c|c|c|c|c|c|c|}
\hline \multicolumn{6}{|c|}{$\begin{array}{l}\text { Dependent variable: } \\
\text { Labor force participation rate of } 65-69 \text { year-old men in the } \\
\text { indicated country, } 1989-2012\end{array}$} & \multicolumn{6}{|c|}{$\begin{array}{l}\text { Dependent variable: } \\
\text { Labor force participation rate of } 65-69 \text { year-old women in } \\
\text { the indicated country, } 1989-2012\end{array}$} \\
\hline \multirow{2}{*}{$\begin{array}{l}\text { Country } \\
\text { Australia }\end{array}$} & \multirow{2}{*}{$\begin{array}{r}\text { Constant } \\
12.4\end{array}$} & \multicolumn{2}{|c|}{ Trend } & \multicolumn{2}{|c|}{ Post-2007 Trend } & \multirow{2}{*}{$\begin{array}{l}\text { Country } \\
\text { United States }\end{array}$} & \multirow{2}{*}{$\begin{array}{r}\text { Constant } \\
14.7\end{array}$} & \multicolumn{2}{|c|}{ Trend } & \multicolumn{2}{|c|}{ Post-2007 Trend } \\
\hline & & 0.70 & $* * *$ & 1.35 & $* * *$ & & & 0.53 & $* * *$ & 0.26 & \\
\hline United States & 24.2 & 0.57 & $* * *$ & 0.12 & & Portugal & 13.9 & 0.53 & $* * *$ & -1.84 & $* * *$ \\
\hline Canada & 14.7 & 0.44 & $* * *$ & 1.48 & $* * *$ & Australia & 3.6 & 0.43 & $* * *$ & 1.38 & $* * *$ \\
\hline United Kingdom & 12.7 & 0.37 & $* * *$ & 0.91 & $* * *$ & Canada & 5.5 & 0.36 & $* * *$ & 1.28 & $* * *$ \\
\hline Netherlands & 8.6 & 0.28 & $* * *$ & 0.92 & $* *$ & Ireland & 3.7 & 0.29 & $* * *$ & 0.22 & \\
\hline Sweden & 15.5 & 0.17 & $* * *$ & 1.19 & $* * *$ & Netherlands & 1.0 & 0.27 & $* * *$ & 0.19 & \\
\hline Austria & 6.1 & 0.14 & & 0.61 & & Sweden & 5.2 & 0.26 & $* * *$ & 0.81 & $* *$ \\
\hline Portugal & 31.7 & 0.14 & $*$ & -1.41 & $* * *$ & United Kingdom & 6.6 & 0.24 & $* * *$ & 1.02 & $* * *$ \\
\hline Belgium & 3.1 & 0.10 & $* * *$ & 0.21 & & Germany & 2.7 & 0.10 & $* * *$ & 0.63 & $* * *$ \\
\hline Finland & 8.1 & 0.09 & & 1.51 & $* * *$ & Finland & 2.9 & 0.07 & & 0.99 & $* * *$ \\
\hline Germany & 6.7 & 0.07 & $* *$ & 1.20 & $* * *$ & Austria & 3.5 & 0.06 & & 0.67 & $* * *$ \\
\hline Spain & 6.5 & -0.01 & & 0.09 & & Belgium & 1.2 & 0.04 & $* *$ & 0.12 & \\
\hline Italy & 11.7 & -0.03 & & 0.26 & & France & 2.5 & -0.03 & $*$ & 0.61 & $* * *$ \\
\hline Ireland & 24.8 & -0.04 & & -0.12 & & Italy & 3.4 & -0.04 & $* * *$ & 0.34 & $* * *$ \\
\hline France & 5.2 & -0.13 & $* * *$ & 1.01 & $* * *$ & Spain & 3.6 & -0.05 & $* *$ & 0.51 & $* * *$ \\
\hline Switzerland & 27.9 & -0.37 & $* * *$ & 1.70 & $* * *$ & Denmark & 7.8 & -0.06 & & 0.55 & \\
\hline Greece & 22.1 & -0.37 & $* * *$ & -0.15 & & Norway & 20.1 & -0.19 & $* *$ & 1.41 & $* * *$ \\
\hline Denmark & 21.6 & -0.41 & $* *$ & 1.63 & $*$ & Greece & 8.5 & -0.19 & $* * *$ & 0.20 & $*$ \\
\hline Japan & 56.5 & -0.52 & $* * *$ & 1.02 & $* * *$ & Japan & 28.3 & -0.23 & $* * *$ & 1.14 & $* * *$ \\
\hline Norway & 36.0 & -0.75 & $* * *$ & 3.13 & $* * *$ & Switzerland & 16.6 & -0.27 & $* * *$ & 1.02 & $* * *$ \\
\hline Average & 17.8 & 0.02 & & 0.83 & & Average & 7.8 & 0.11 & & 0.57 & \\
\hline
\end{tabular}

Notes: The estimation equation for each country is: $L=\alpha+\beta(y-1989)+\delta(y-2007)$, where $y$ is the calendar year, $L_{y}$ is the labor force participation rate in year $y, \beta$ is the coefficient on calendar year, and $\delta$ is the deviation in the time trend effect after 2007. Estimates were obtained using data for 1989-2012. Asterisks indicate statistical significance under a two-tailed t-test ( $* * *$ indicates $P<0.01$, $* *$ indicates $P<0.05$, and $*$ indicates $P<0.10$ ). Countries are ranked by the rate of participation-rate gain through 2007. 
Table 3. Regression Estimates of Labor Force Participation Trends before and after 2007 in Nineteen OECD Countries: Men and Women Aged 70-74

\begin{tabular}{|c|c|c|c|c|c|c|c|c|c|c|c|}
\hline \multicolumn{6}{|c|}{$\begin{array}{l}\text { Dependent variable: } \\
\text { Labor force participation rate of } 70-74 \text { year-old men in the } \\
\text { indicated country, } 1989-2012\end{array}$} & \multicolumn{6}{|c|}{$\begin{array}{l}\text { Dependent variable: } \\
\text { Labor force participation rate of } 70-74 \text { year-old women in } \\
\text { the indicated country, } 1989-2012\end{array}$} \\
\hline \multirow{2}{*}{ Country } & \multirow{2}{*}{$\begin{array}{r}\text { Constant } \\
18.6\end{array}$} & \multicolumn{2}{|c|}{ Trend } & \multicolumn{2}{|c|}{ Post-2007 Trend } & \multirow{2}{*}{ Country } & \multirow{2}{*}{$\begin{array}{r}\text { Constant } \\
7.0\end{array}$} & \multicolumn{2}{|c|}{ Trend } & \multicolumn{2}{|c|}{ Post-2007 Trend } \\
\hline & & 0.49 & $* * *$ & -1.30 & $* * *$ & & & 0.53 & $* * *$ & -1.65 & $* * *$ \\
\hline United States & 14.2 & 0.36 & $* * *$ & 0.33 & $* *$ & United States & 7.0 & 0.34 & $* * *$ & 0.15 & \\
\hline Netherlands & 4.3 & 0.16 & $* *$ & 0.43 & & Japan & 12.1 & 0.21 & & 0.66 & \\
\hline Norway & 5.0 & 0.15 & $*$ & 0.55 & $* *$ & Norway & 1.0 & 0.18 & $* * *$ & -0.05 & \\
\hline Canada & 8.4 & 0.10 & $* * *$ & 1.23 & $* * *$ & Denmark & 0.8 & 0.10 & & 0.07 & \\
\hline Belgium & 1.5 & 0.08 & $* *$ & -0.02 & & Canada & 2.6 & 0.08 & $* * *$ & 0.67 & $* * *$ \\
\hline Austria & 4.1 & 0.06 & & 0.71 & $* *$ & United Kingdom & 2.7 & 0.07 & $* * *$ & 0.36 & $* * *$ \\
\hline United Kingdom & 7.0 & 0.02 & & 0.72 & $* * *$ & Netherlands & 0.9 & 0.06 & $* * *$ & 0.28 & $* *$ \\
\hline Japan & 29.7 & 0.01 & & 0.18 & & Austria & 1.6 & 0.06 & & 0.32 & $*$ \\
\hline Germany & 4.0 & -0.01 & & 0.59 & $* * *$ & France & 0.1 & 0.04 & & 0.02 & \\
\hline Spain & 2.2 & -0.01 & & 0.06 & & Ireland & 2.6 & 0.03 & & 0.11 & \\
\hline Finland & 5.0 & -0.02 & & 0.74 & $* *$ & Belgium & 0.2 & 0.03 & & 0.06 & \\
\hline Italy & 5.6 & -0.03 & & 0.28 & $* *$ & Germany & 1.6 & 0.01 & & 0.31 & $* * *$ \\
\hline Sweden & 10.7 & -0.06 & & 0.32 & & Finland & 1.3 & 0.01 & & 0.32 & $* * *$ \\
\hline France & 2.6 & -0.07 & $* * *$ & 0.25 & $* * *$ & Spain & 1.1 & -0.02 & $* *$ & 0.13 & $* *$ \\
\hline Denmark & 9.9 & -0.11 & $*$ & 0.59 & $*$ & Italy & 1.7 & -0.03 & $* * *$ & 0.06 & \\
\hline Ireland & 15.9 & -0.12 & $* *$ & 0.05 & & Sweden & 3.2 & -0.04 & & 0.61 & $* * *$ \\
\hline Greece & 10.3 & -0.28 & $* * *$ & 0.09 & & Greece & 3.7 & -0.13 & $* * *$ & 0.16 & $*$ \\
\hline Switzerland & 19.3 & -0.37 & $* * *$ & 0.97 & $* * *$ & Switzerland & 9.7 & -0.30 & $* * *$ & 0.84 & $* * *$ \\
\hline Average & 9.4 & 0.02 & & 0.36 & & Average & 3.2 & 0.06 & & 0.18 & \\
\hline
\end{tabular}

Notes: The estimation equation for each country is: $L=\alpha+\beta(y-1989)+\delta(y-2007)$, where $y$ is the calendar year, $L_{y}$ is the labor force participation rate in year $y, \beta$ is the coefficient on calendar year, and $\delta$ is the deviation in the time trend effect after 2007. Estimates were obtained using data for 1989-2012. Asterisks indicate statistical significance under a two-tailed t-test ( $* * *$ indicates $P<0.01, * *$ indicates $P<0.05$, and * indicates $P<0.10$ ). Countries are ranked by the rate of participation-rate gain through 2007. 
Figure 1. Change in Male Labor Force Participation Rate, by Age Group, in the U.S. and Europe, 1994-2007 (Percentage point change)
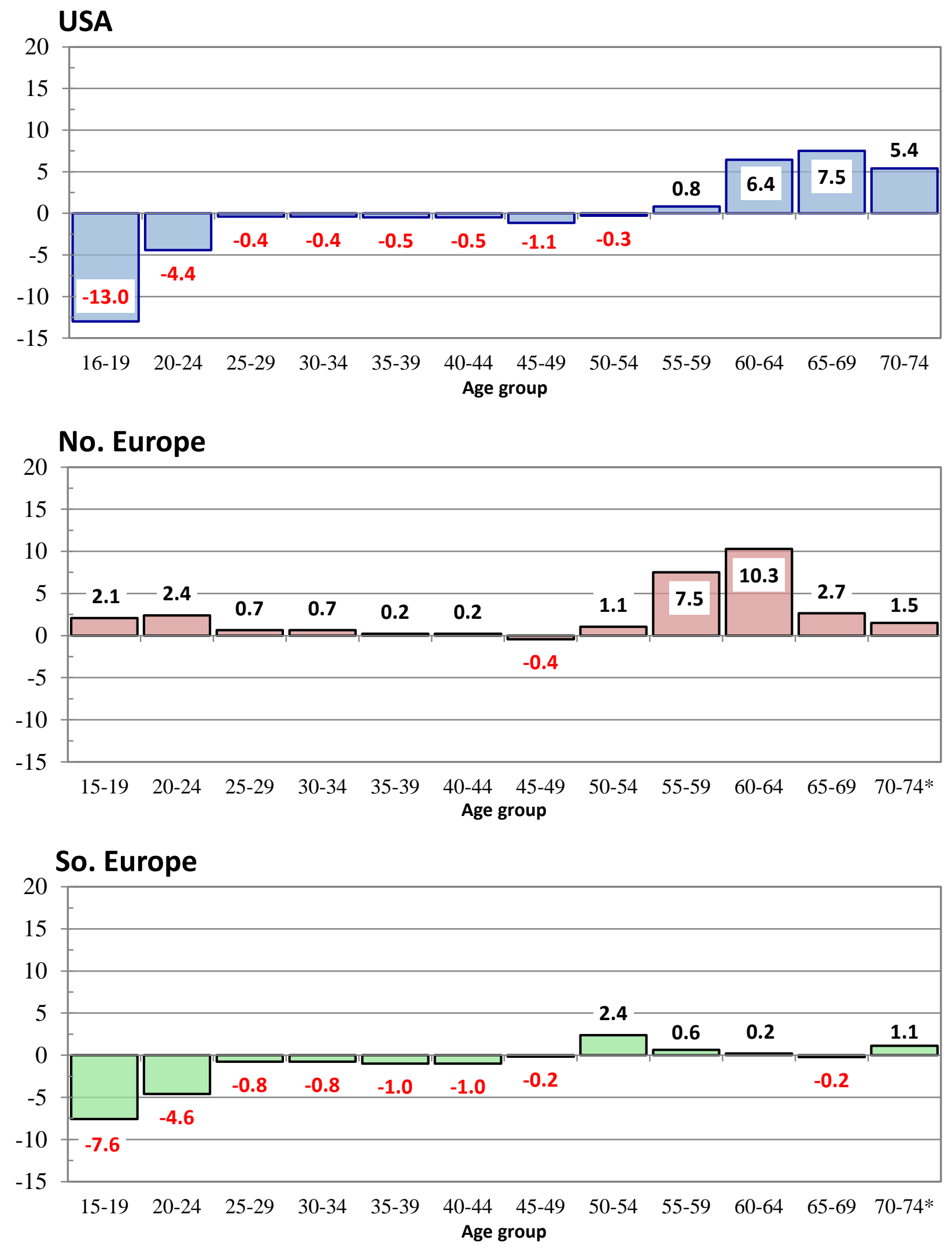

Source: OECD and Eurostat labor force statistics. 
Figure 2. Change in Women's Labor Force Participation Rate, by Age Group, in the U.S. and Europe, 1994-2007 (Percentage point change)


So. Europe

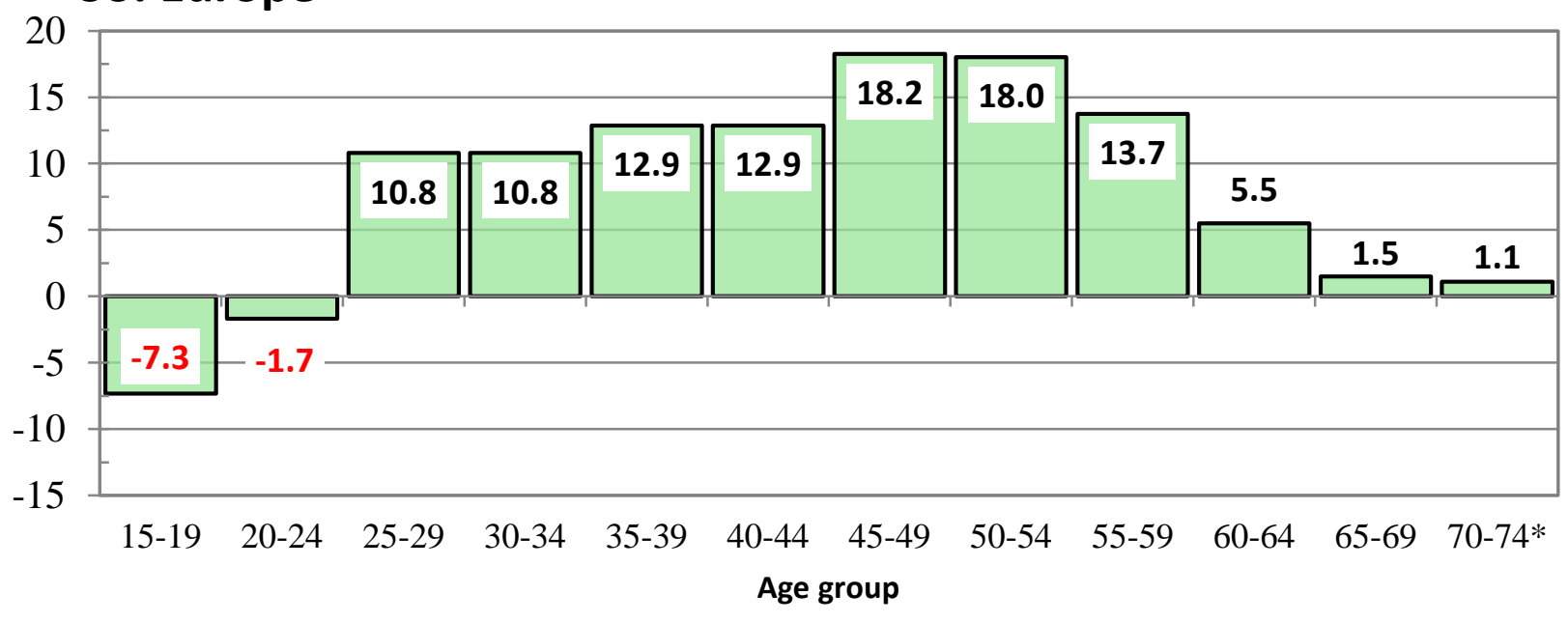

Source: OECD and Eurostat labor force statistics. 
Figure 3. Indicators of Economic Slack in Major Industrial Countries, 1989-2012

Annual Percent Change in Real GDP in 20 OECD Countries



\section{Output Gap in 19 OECD Countries*}

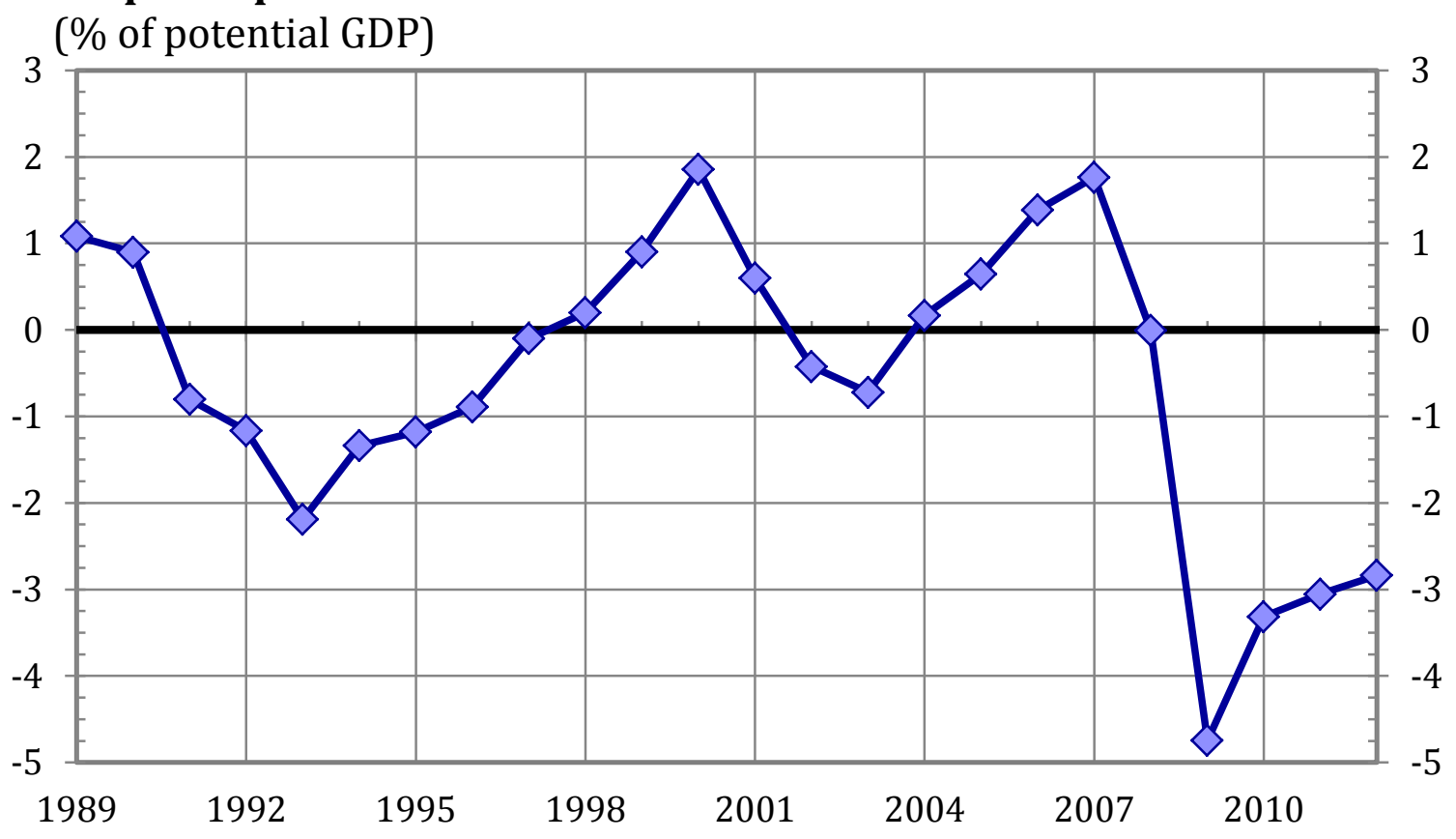

* Switzerland is excluded because estimates of potential Swiss GDP are not available. Source: IMF, World Economic Outlook, October 2013. 
Figure 4. Average Unemployment Rates of 15-64 Year-olds in OECD Countries, 1989-2012

Australia, Canada, and the U.S.

(\% of labor force)

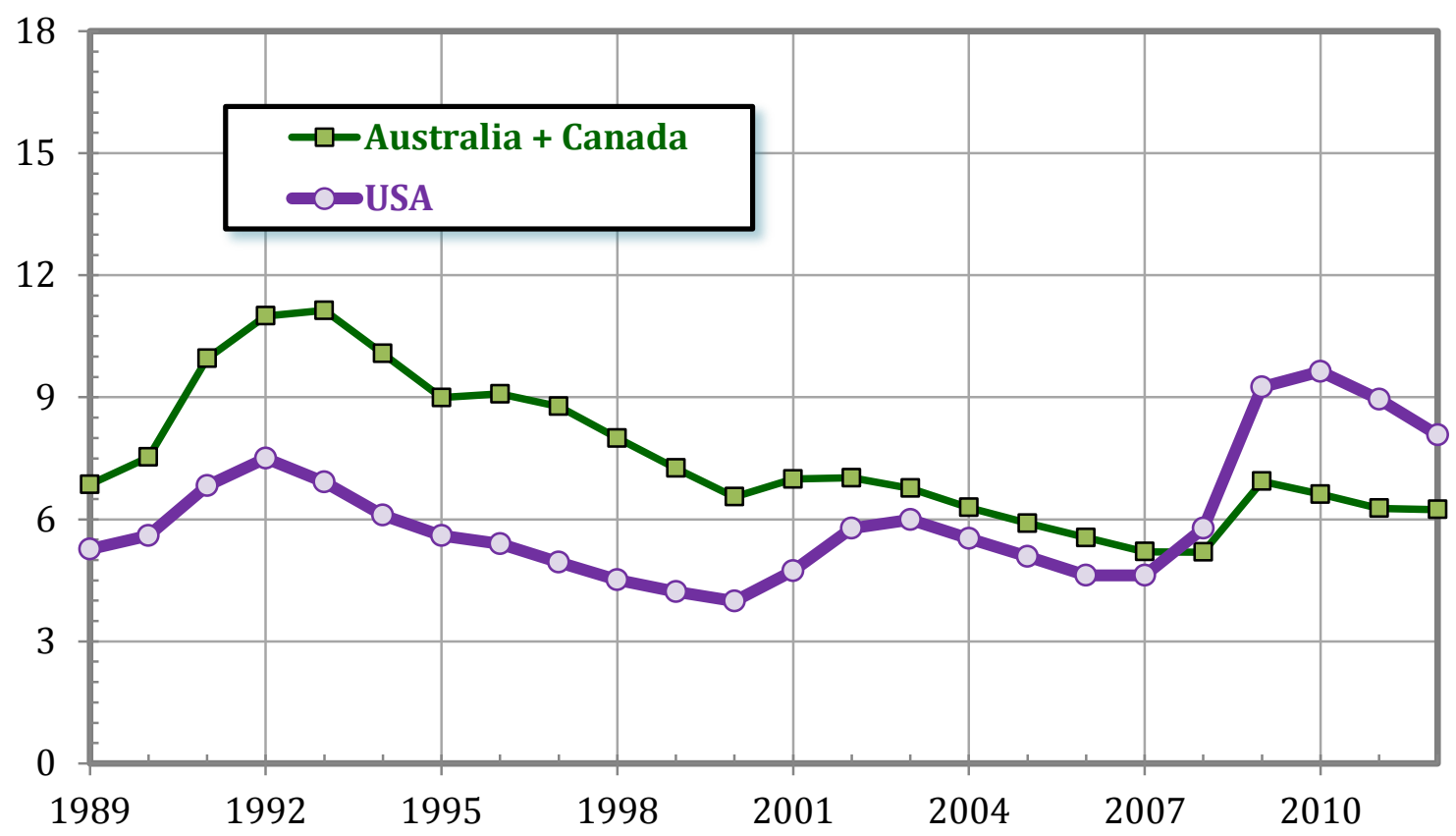

Europe and Japan

( $\%$ of labor force)

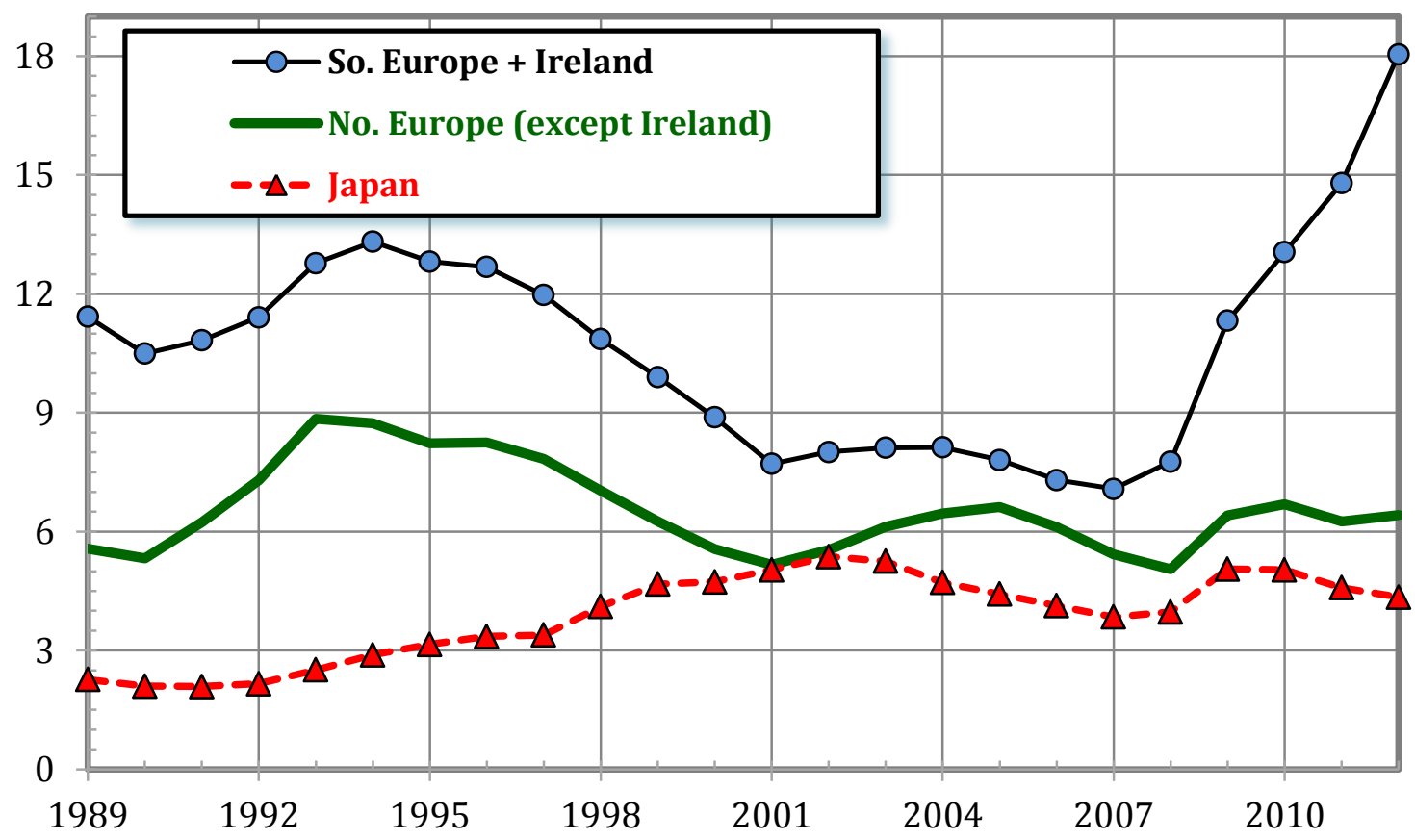

Source: OECD labor force statistics. 
Figure 5. Trends in Old-Age Labor Force Participation in Selected OECD Countries Ranked by Their Participation Rates in 1989

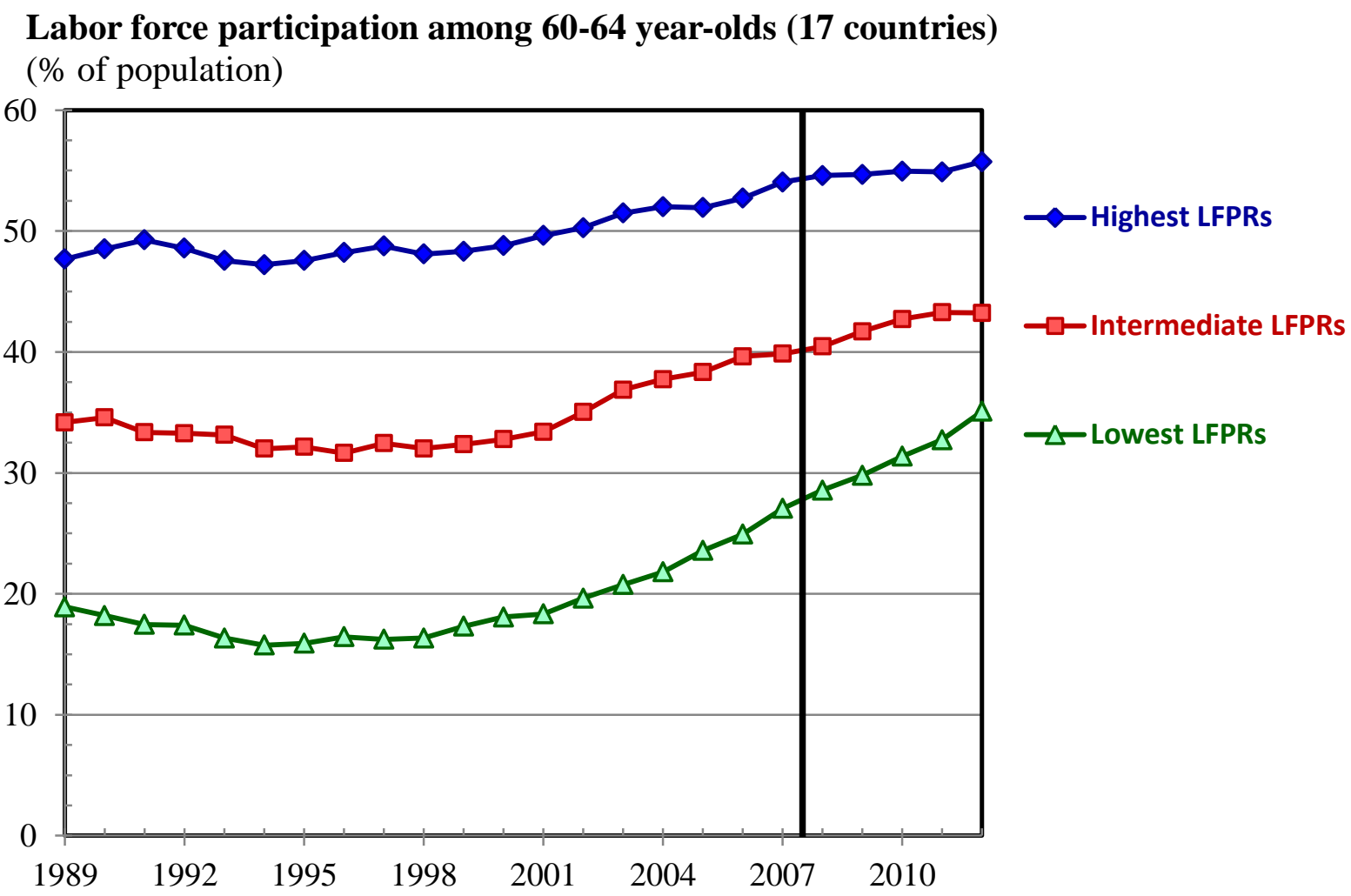

Labor force participation among 65-69 year-olds (17 countries) (\% of population)

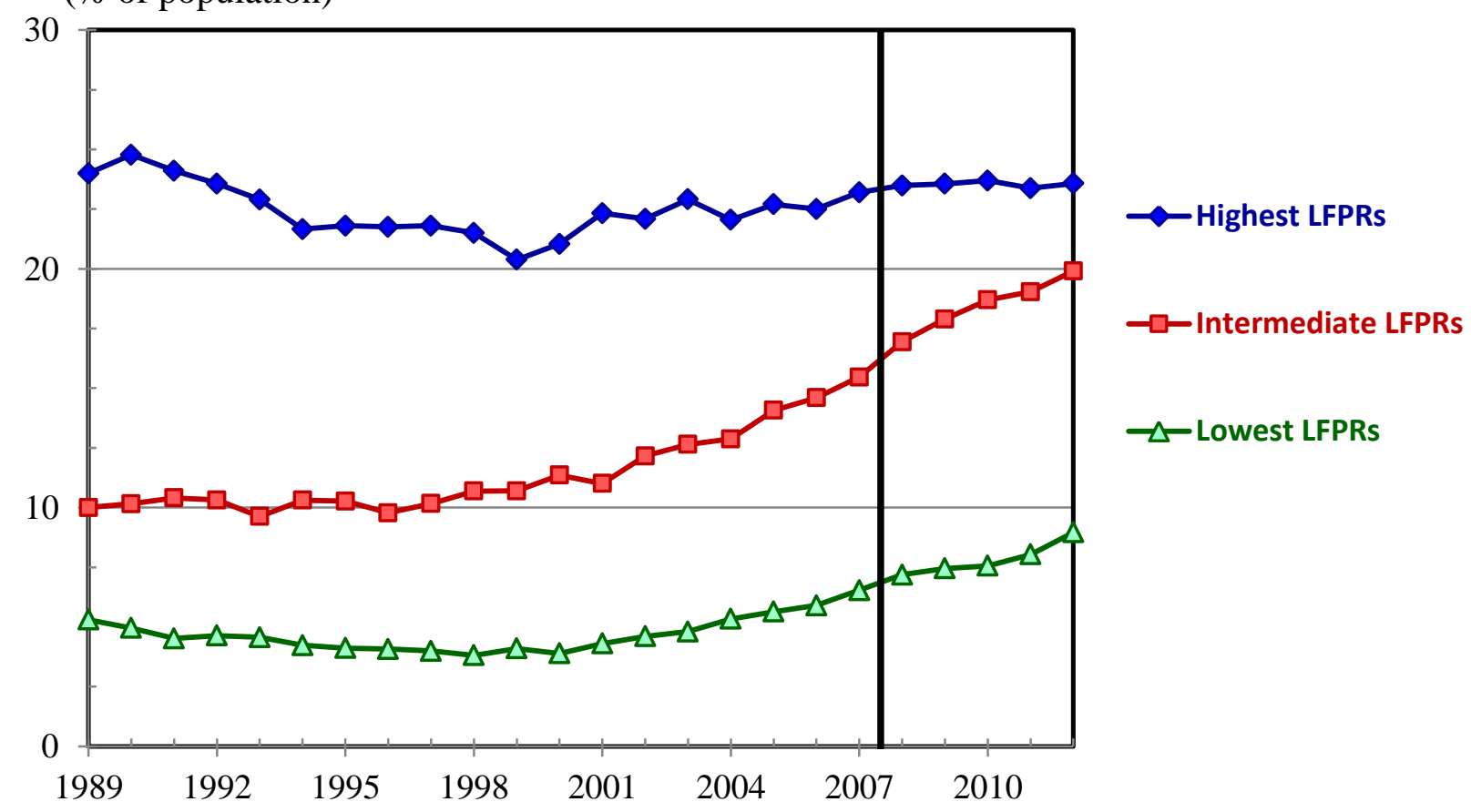


Figure 5. Trends in Old-Age Labor Force Participation in Selected OECD Countries Ranked by Their Participation Rates in 1989 (continued)

\section{Labor force participation among 70-74 year-olds (13 countries)}

(\% of population)

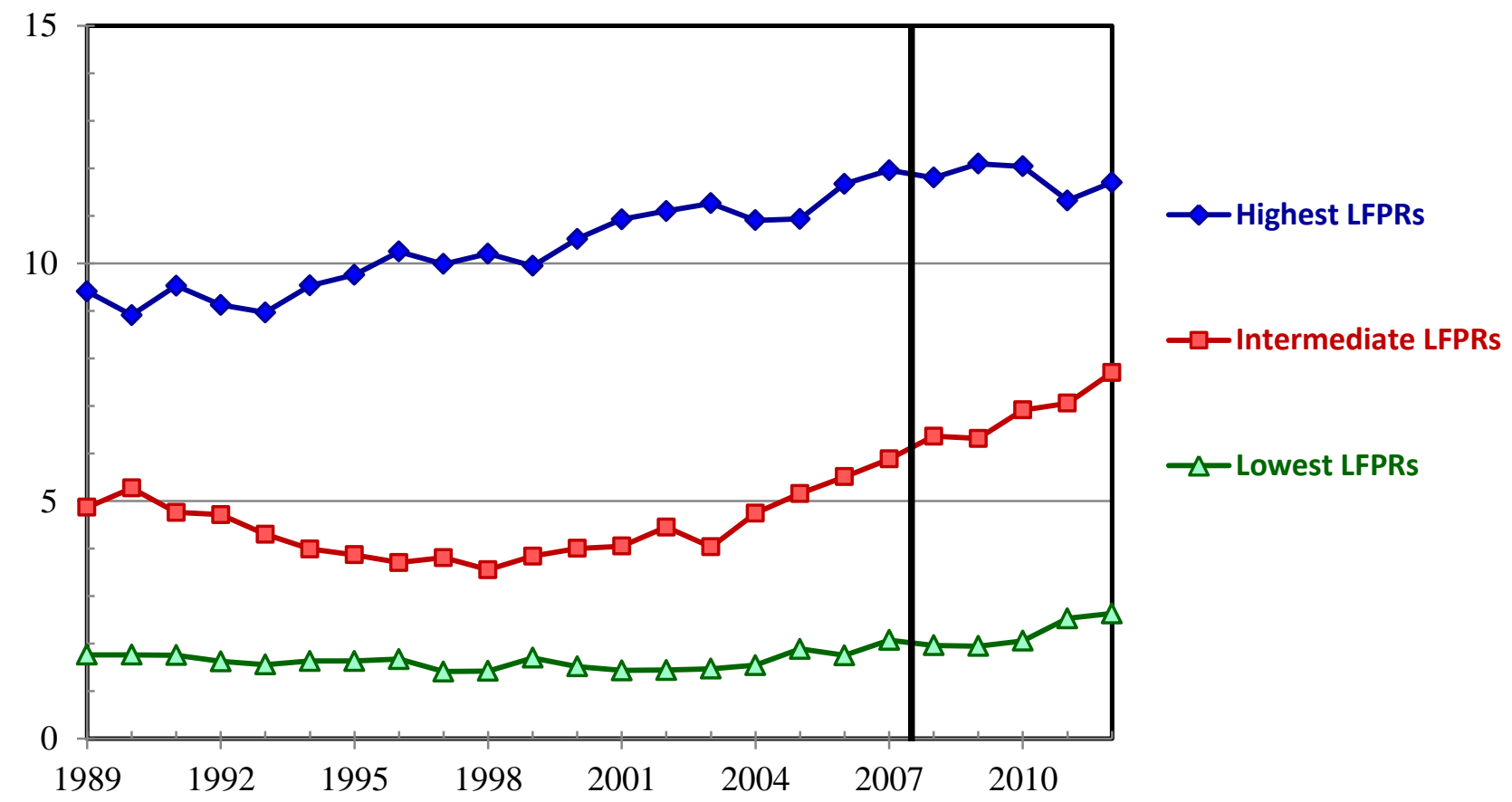

Source: OECD and Eurostat labor force statistics.

Note: Identification of countries in each group ranked by their LFPRs in 1989:

\begin{tabular}{|c|c|c|}
\hline Age 60-64 & Age 65-69 & Age 70-74 \\
Belgium & Lowest participation rates in 1989: & \\
Finland & Belgium & Belgium \\
France & Finland & France \\
Germany & France & Germany \\
Italy & Germany & Spain \\
Netherlands & Netherlands & \\
& Spain & \\
Australia & Intermediate participation rates in 1989: & Canada \\
Canada & Australia & Denmark \\
Denmark & Canada & Finland \\
Greece & Italy & Netherlands \\
Spain & Sweden & United Kingdom \\
& United Kingdom & \\
Japan & Highest participation rates in 1989: & Greece \\
Norway & Denmark & Portugal \\
Portugal & Greece & Sweden \\
Sweden & Japan & United States \\
United Kingdom & Norway & \\
United States & Portugal &
\end{tabular}


Figure 6. Correlation of Participation Rate Increases among Older Men and Older Women in OECD Countries, 2007 to 2012
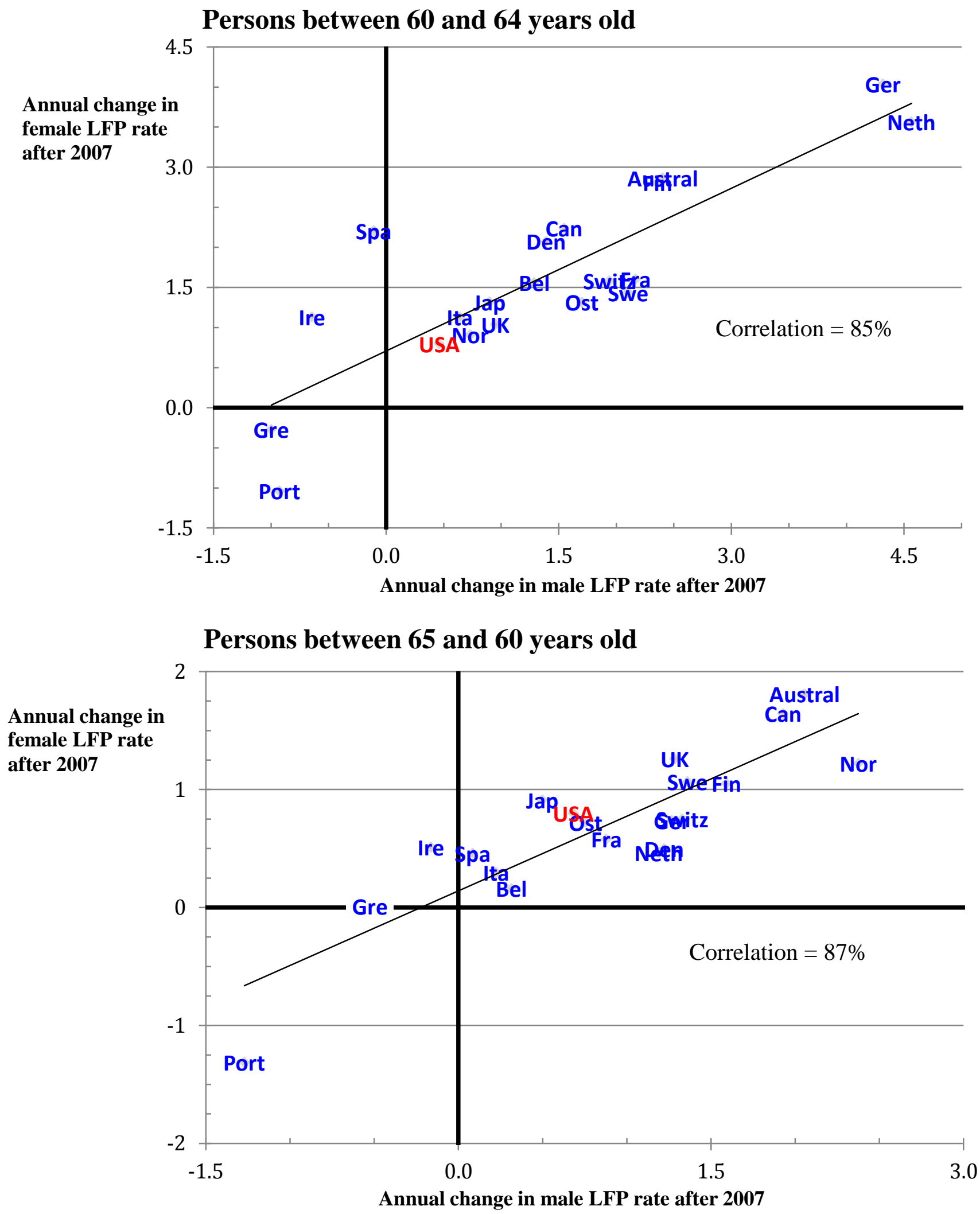
Figure 6. Correlation of Participation Rate Increases among Older Men and Older Women in OECD Countries, 2007 to 2012 (Continued)



Source: Authors' tabulations of OECD and Eurostat labor force statistics as explained in text. 
Figure 7. Correlation of Participation Rate Increases and Changes in Unemployment Rate after 2007

Participation rate changes among people 60-64 years old

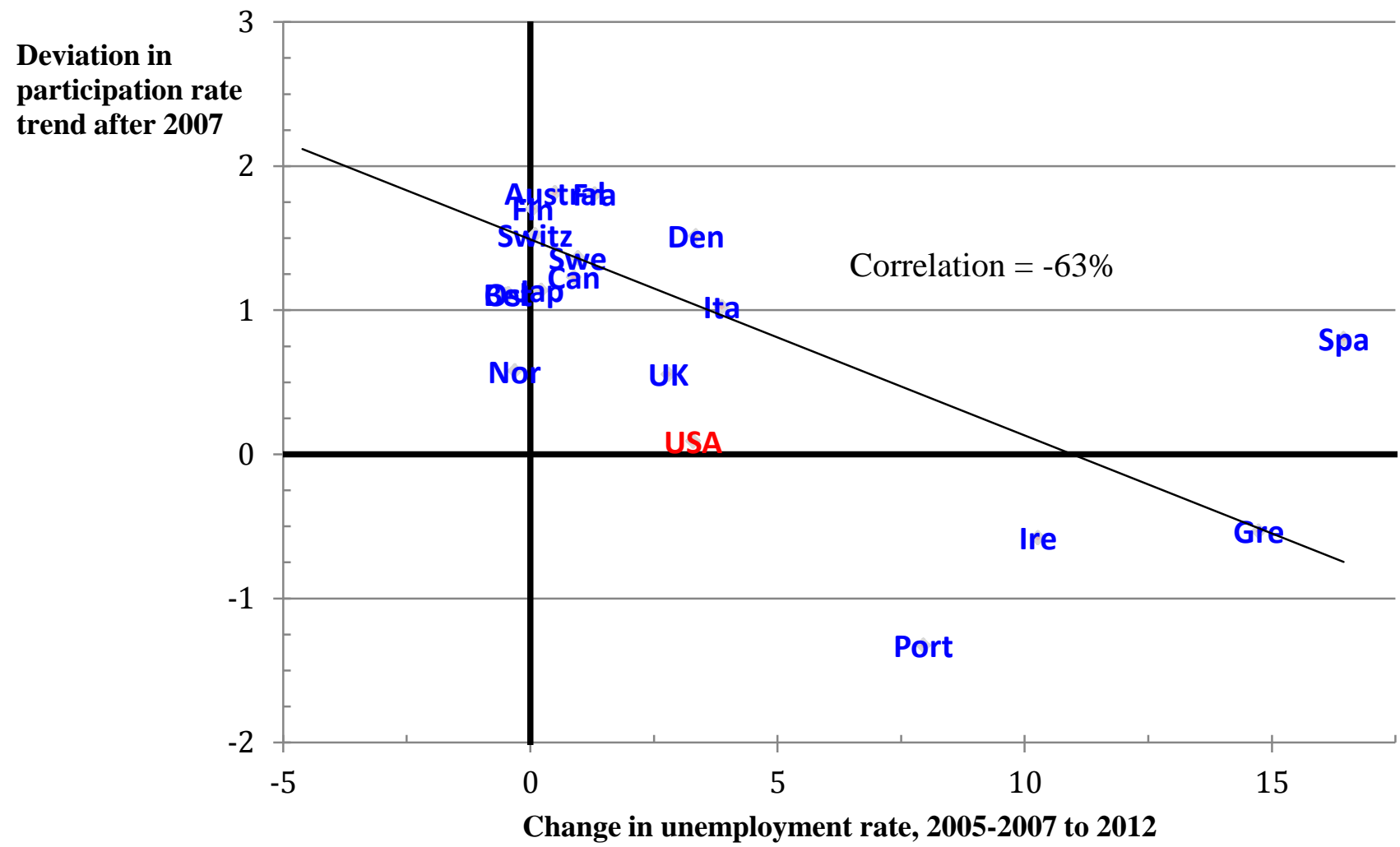

Participation rate changes among people 65-69 years old

Deviation in participation rate trend after 2007

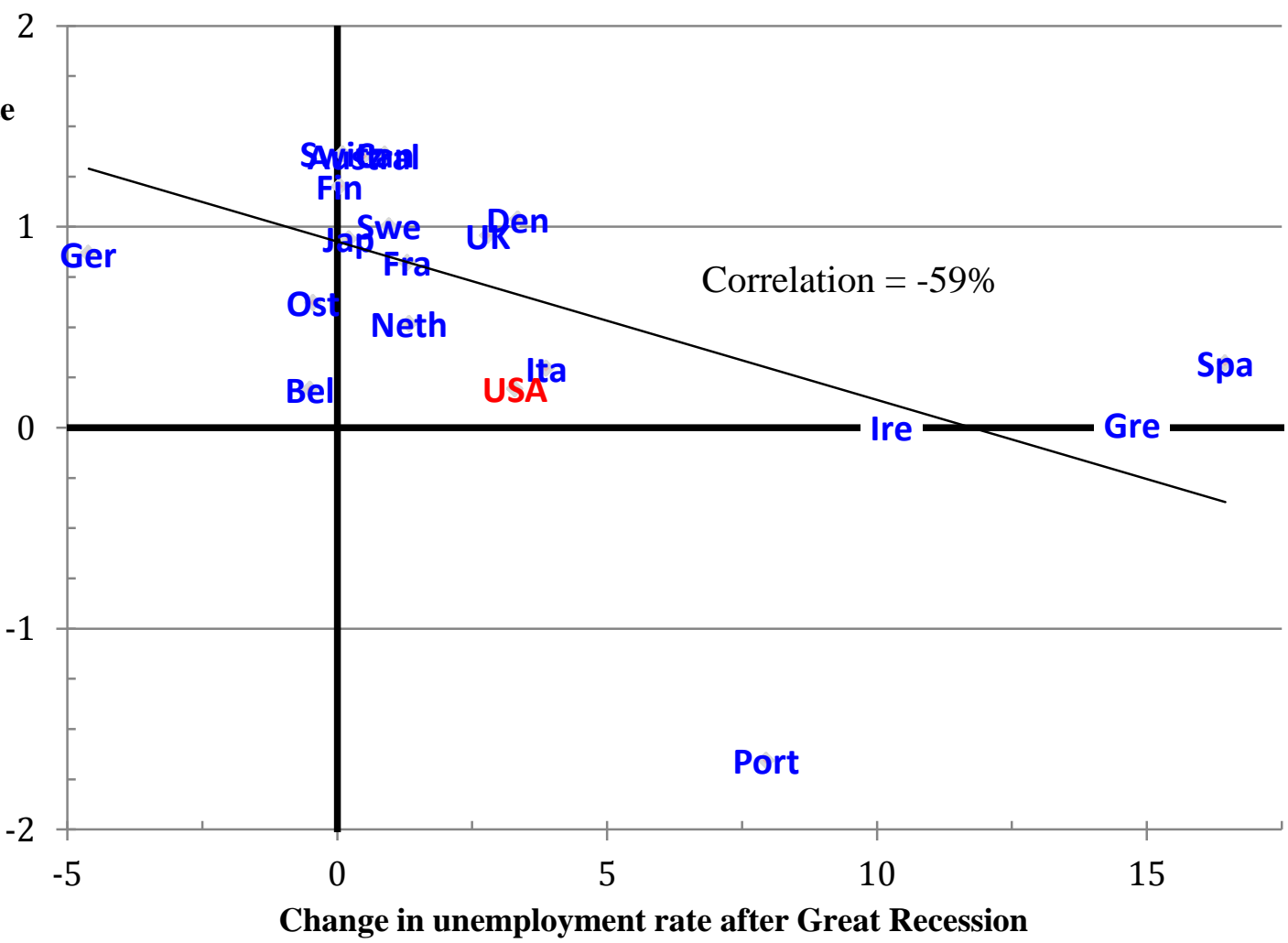


Figure 8a. Employment-Population Ratios among Prime-age and 60-64 Year-old Adults in OECD Countries, 2007 and 2012

Employment rate of population age 25-54

(\%)

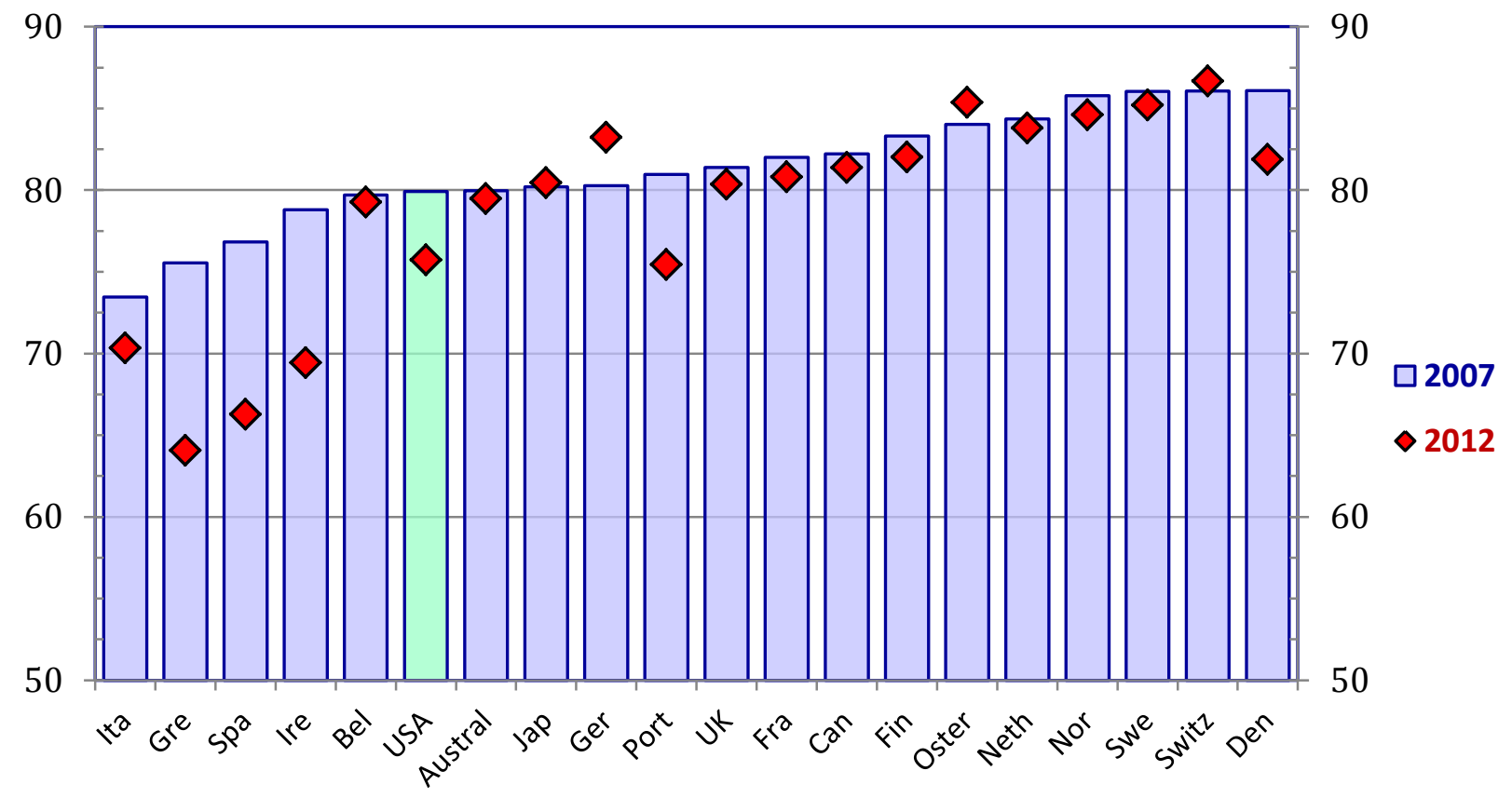

Employment rate of population age 60-64

$(\%)$

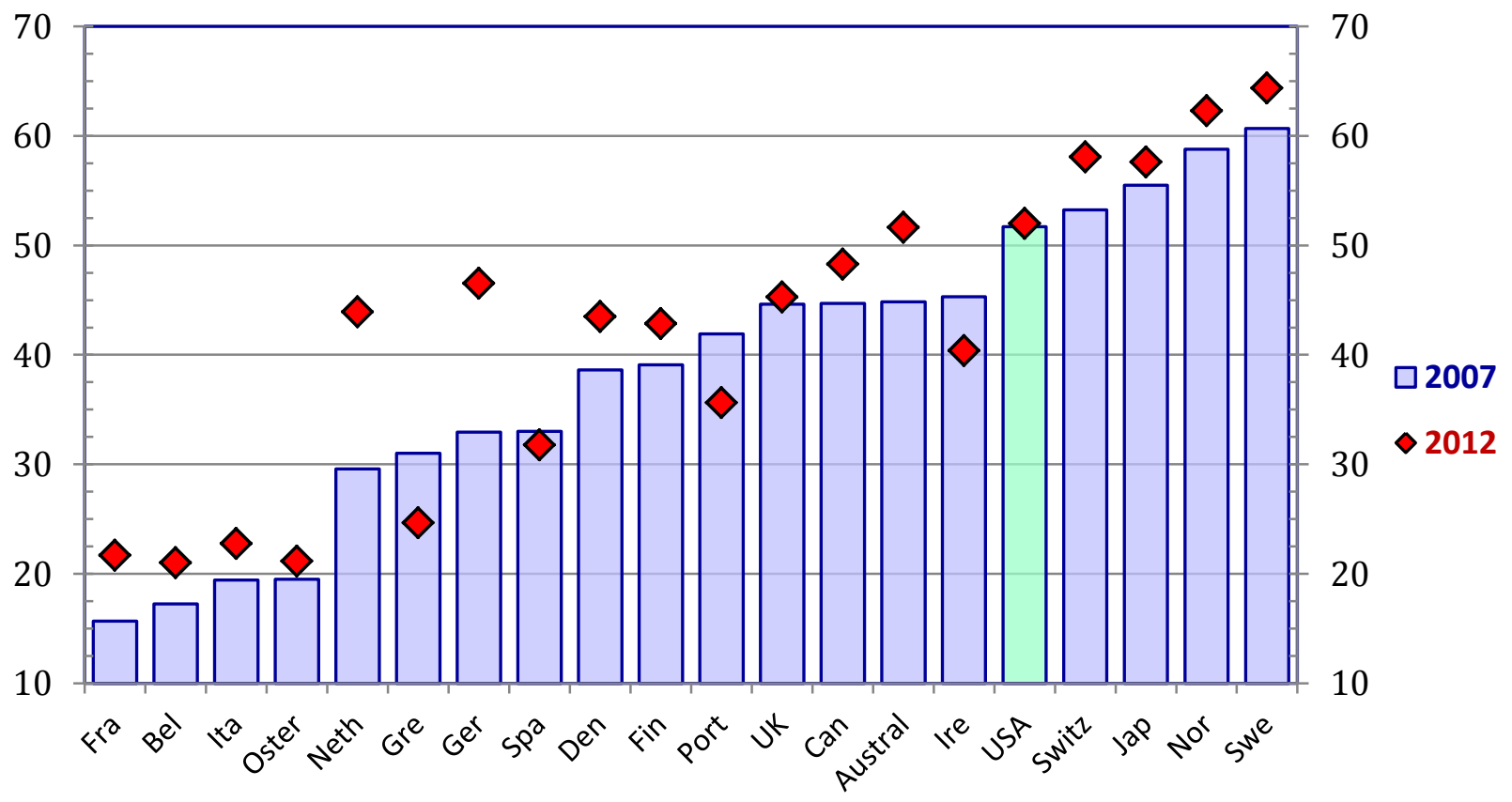

Source: Authors' tabulations of OECD and Eurostat labor force statistics as explained in text. 
Figure 8b. Employment-Population Ratios among 65-69 and 70-74 Year-old Adults in OECD Countries, 2007 and 2012

\section{Employment rate of population age 65-69}

$(\%)$

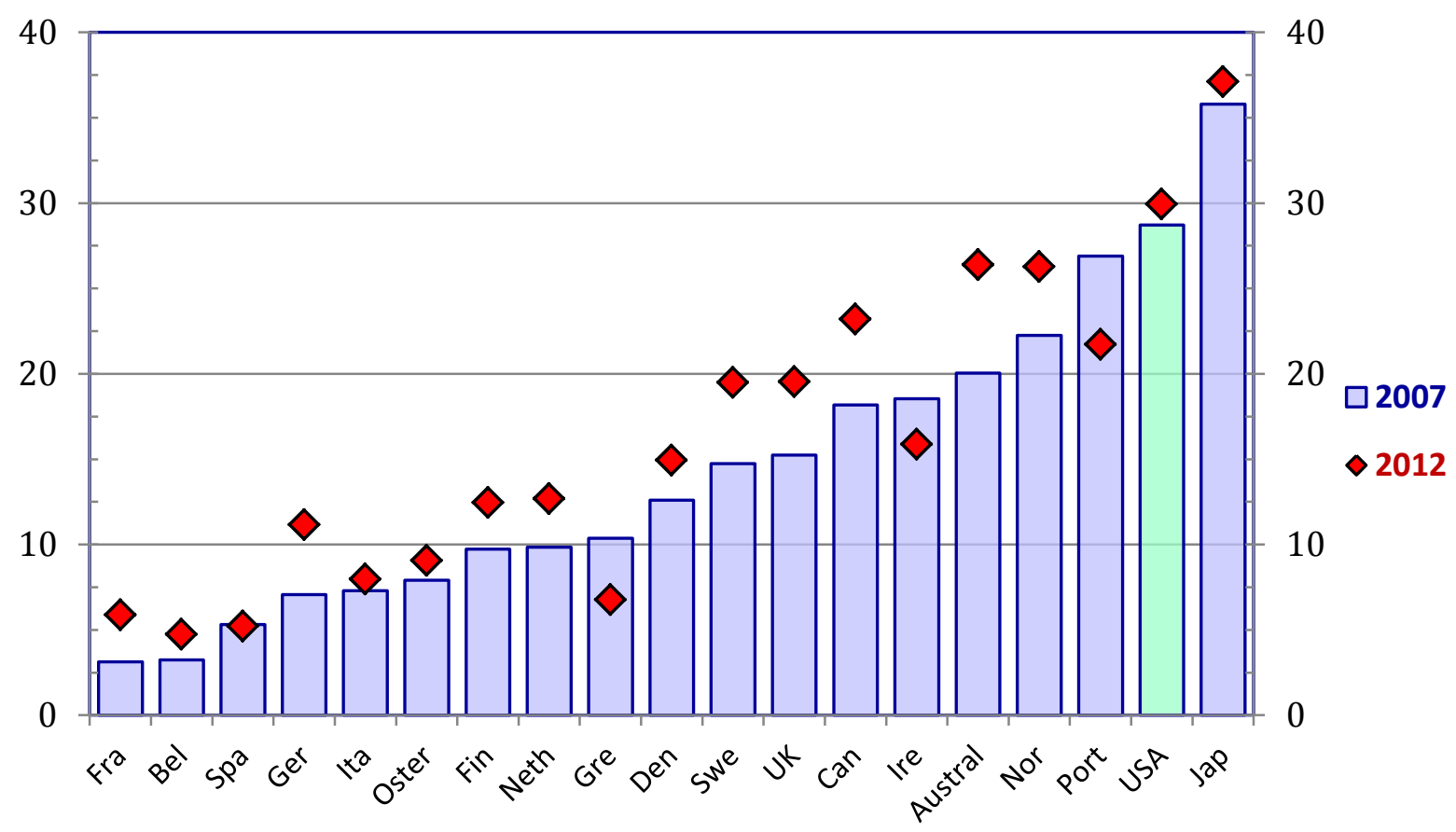

Employment rate of population age 70-74

(\%)

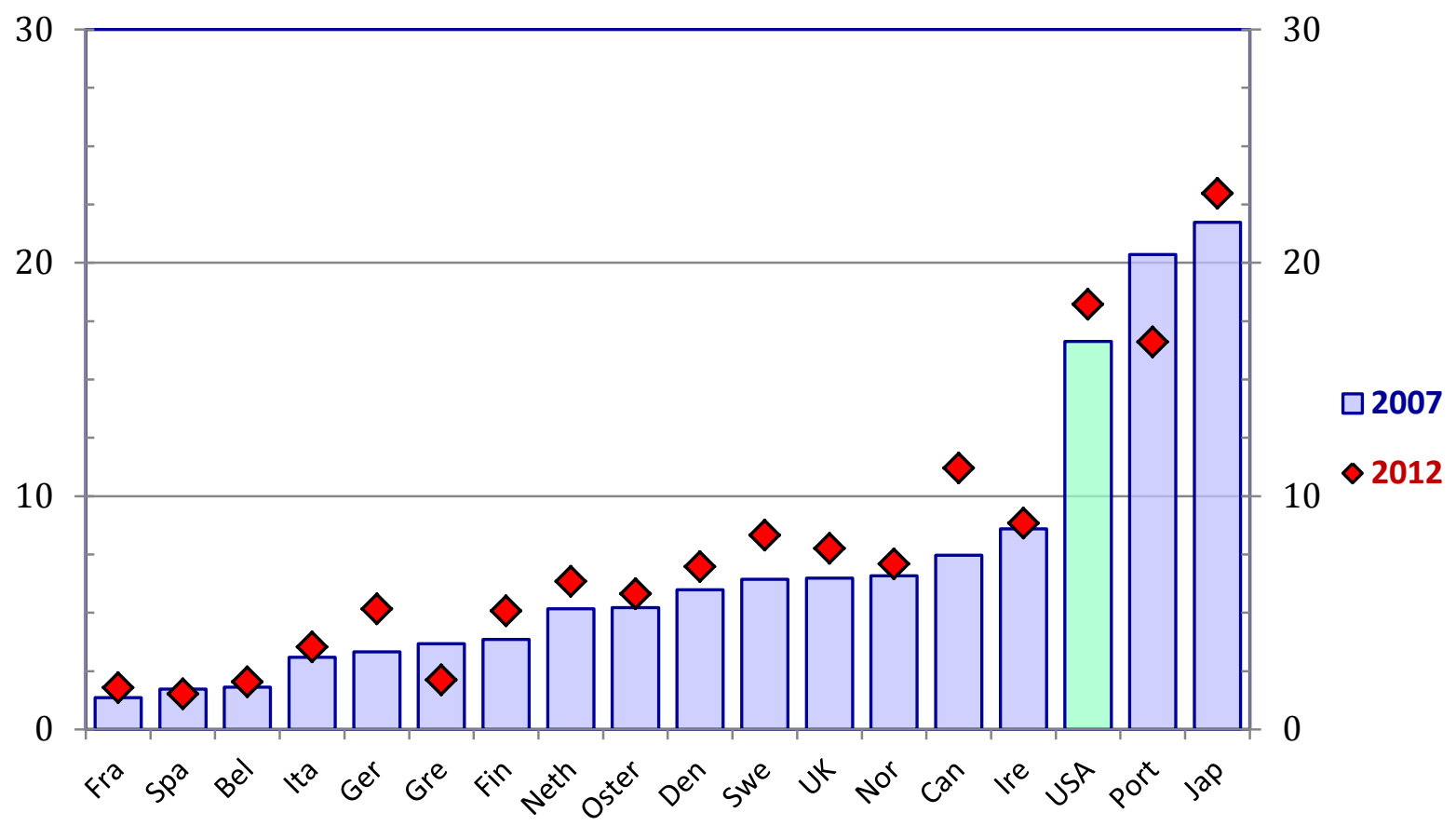

Source: Authors' tabulations of OECD and Eurostat labor force statistics as explained in text. 


\section{Appendix Table A1. Regression Estimates of Labor Force Participation Trends before and after 2007 in Twenty OECD Countries: Men and Women Aged 60-64}

\begin{tabular}{|c|c|c|c|c|c|c|c|c|c|c|c|}
\hline \multicolumn{6}{|c|}{$\begin{array}{l}\text { Dependent variable: } \\
\text { Labor force participation rate of 60-64 year-old men in the } \\
\text { indicated country, 1994-2012 }\end{array}$} & \multicolumn{6}{|c|}{$\begin{array}{l}\text { Dependent variable: } \\
\text { Labor force participation rate of 60-64 year-old women in the } \\
\text { indicated country, } 1994-2012\end{array}$} \\
\hline \multirow{2}{*}{$\begin{array}{l}\text { Country } \\
\text { Finland }\end{array}$} & \multirow{2}{*}{$\begin{array}{r}\text { Constant } \\
20.0\end{array}$} & \multicolumn{2}{|c|}{ Trend } & \multicolumn{2}{|c|}{ Post-2007 Trend } & \multirow{2}{*}{$\begin{array}{l}\text { Country } \\
\text { Finland }\end{array}$} & \multirow{2}{*}{$\begin{array}{r}\text { Constant } \\
13.5\end{array}$} & \multicolumn{2}{|c|}{ Trend } & \multicolumn{2}{|c|}{ Post-2007 Trend } \\
\hline & & 1.57 & $* * *$ & -0.17 & & & & 1.71 & $* * *$ & 0.16 & \\
\hline Netherlands & 17.6 & 1.55 & $* * *$ & 2.30 & $* * *$ & Australia & 13.5 & 1.61 & $* * *$ & 0.76 & $*$ \\
\hline Germany & 25.2 & 1.31 & $* * *$ & 2.24 & $* * *$ & Canada & 20.8 & 1.33 & $* * *$ & 0.41 & \\
\hline Canada & 42.6 & 0.91 & $* * *$ & -0.05 & & Ireland & 13.7 & 1.27 & $* * *$ & -0.29 & \\
\hline Australia & 44.1 & 0.82 & $* * *$ & 1.00 & $* *$ & Netherlands & 5.5 & 1.13 & $* * *$ & 2.01 & $* * *$ \\
\hline Spain & 39.9 & 0.75 & $* * *$ & -1.52 & $* * *$ & Switzerland & 29.9 & 1.05 & $* * *$ & 0.23 & \\
\hline United Kingdom & 48.2 & 0.70 & $* * *$ & -0.30 & & Sweden & 45.5 & 1.01 & $* * *$ & -0.24 & \\
\hline Austria & 14.5 & 0.67 & $* * *$ & 1.03 & & United States & 36.5 & 0.88 & $* * *$ & -0.24 & \\
\hline France & 10.1 & 0.46 & $* * *$ & 1.18 & $* * *$ & Spain & 13.9 & 0.57 & $* * *$ & 1.38 & $* * *$ \\
\hline Denmark & 42.7 & 0.41 & $*$ & 0.42 & & Belgium & 3.7 & 0.52 & $* * *$ & 0.89 & $* * *$ \\
\hline Norway & 61.6 & 0.15 & & 0.40 & & Norway & 46.8 & 0.48 & $* * *$ & 0.38 & $*$ \\
\hline Portugal & 53.7 & -0.10 & & -0.99 & $* * *$ & France & 9.9 & 0.29 & $* * *$ & 1.06 & $* * *$ \\
\hline Greece & 46.5 & -0.14 & & -0.84 & $* *$ & Italy & 7.7 & 0.19 & $* * *$ & 0.75 & $* * *$ \\
\hline Italy & 32.0 & -0.19 & $* * *$ & 0.66 & $* * *$ & Japan & 38.9 & 0.16 & $* * *$ & 1.06 & $* * *$ \\
\hline Japan & 74.5 & -0.19 & $*$ & 1.21 & $* * *$ & Austria & 8.1 & 0.12 & & 1.19 & $* * *$ \\
\hline Switzerland & 71.2 & -0.55 & $* * *$ & 2.24 & $* * *$ & Greece & 19.7 & 0.08 & & -0.30 & \\
\hline Average & 41.0 & 0.53 & & 0.41 & & Average & 20.4 & 0.80 & & 0.52 & \\
\hline
\end{tabular}

Notes: The estimation equation for each country is: $L=\alpha+\beta(y-1994)+\delta(y-2007)$, where $y$ is the calendar year, $L_{y}$ is the labor force participation rate in year $y, \beta$ is the coefficient on calendar year, and $\delta$ is the deviation in the time trend effect after 2007. Estimates were obtained using data for 19942012. Asterisks indicate statistical significance under a two-tailed t-test (*** indicates $P<0.01$, ** indicates $P<0.05$, and $*$ indicates $P<0.10$ ). Countries are ranked by the rate of participation-rate gain through 2007. 


\section{Appendix Table A2. Regression Estimates of Labor Force Participation Trends before and after 2007 in Twenty OECD Countries: Men and Women Aged 65-69}

\begin{tabular}{|c|c|c|c|c|c|c|c|c|c|c|c|}
\hline \multicolumn{6}{|c|}{$\begin{array}{l}\text { Dependent variable: } \\
\text { Labor force participation rate of } 65-69 \text { year-old men in the } \\
\text { indicated country, 1994-2012 }\end{array}$} & \multicolumn{6}{|c|}{$\begin{array}{l}\text { Dependent variable: } \\
\text { Labor force participation rate of } 65-69 \text { year-old women in } \\
\text { the indicated country, } 1994-2012\end{array}$} \\
\hline \multirow{2}{*}{$\begin{array}{l}\text { Country } \\
\text { Australia }\end{array}$} & \multirow{2}{*}{$\begin{array}{r}\text { Constant } \\
14.8\end{array}$} & \multicolumn{2}{|c|}{ Trend } & \multicolumn{2}{|c|}{ Post-2007 Trend } & \multirow{2}{*}{$\begin{array}{l}\text { Country } \\
\text { United States }\end{array}$} & \multirow{2}{*}{ Constant } & \multicolumn{2}{|c|}{ Trend } & \multicolumn{2}{|c|}{ Post-2007 Trend } \\
\hline & & 0.83 & $* * *$ & 1.06 & $* * *$ & & & 0.70 & $* * *$ & -0.11 & \\
\hline Canada & 14.7 & 0.70 & $* * *$ & 0.92 & $* *$ & Portugal & 16.3 & 0.56 & $* * *$ & -1.92 & $* * *$ \\
\hline United States & 26.2 & 0.67 & $* * *$ & -0.12 & & Canada & 5.7 & 0.55 & $* * *$ & 0.87 & $* * *$ \\
\hline United Kingdom & 12.7 & 0.59 & $* * *$ & 0.43 & & Australia & 4.9 & 0.54 & $* * *$ & 1.14 & $* * *$ \\
\hline Netherlands & 7.9 & 0.52 & $* * *$ & 0.38 & & Sweden & 4.3 & 0.50 & $* * *$ & 0.26 & \\
\hline Denmark & 11.9 & 0.47 & $* * *$ & -0.29 & & Netherlands & 1.2 & 0.40 & $* * *$ & -0.09 & \\
\hline Finland & 5.9 & 0.40 & $* * *$ & 0.80 & $* * *$ & Ireland & 4.5 & 0.36 & $* * *$ & 0.06 & \\
\hline Spain & 4.6 & 0.21 & $* * *$ & -0.38 & $* *$ & United Kingdom & 6.9 & 0.34 & $* * *$ & 0.79 & $* * *$ \\
\hline Sweden & 16.3 & 0.18 & $*$ & 1.17 & $* * *$ & Finland & 1.6 & 0.26 & $* * *$ & 0.55 & $* * *$ \\
\hline Germany & 6.3 & 0.15 & $* * *$ & 1.01 & $* * *$ & Denmark & 5.2 & 0.22 & $*$ & -0.03 & \\
\hline Italy & 10.1 & 0.14 & $* * *$ & -0.14 & & Norway & 15.8 & 0.19 & $*$ & 0.57 & \\
\hline Austria & 6.8 & 0.14 & & 0.61 & & Germany & 2.5 & 0.18 & $* * *$ & 0.46 & $* * *$ \\
\hline Belgium & 3.3 & 0.14 & $* *$ & 0.13 & & Austria & 3.7 & 0.06 & & 0.67 & $* * *$ \\
\hline Portugal & 33.1 & 0.06 & & -1.26 & $* * *$ & Spain & 2.7 & 0.03 & & 0.33 & $* * *$ \\
\hline Ireland & 23.9 & 0.05 & & -0.31 & & Belgium & 1.7 & 0.01 & & 0.18 & $*$ \\
\hline Norway & 26.1 & -0.03 & & 1.50 & $* *$ & France & 2.0 & 0.01 & & 0.52 & $* * *$ \\
\hline France & 3.7 & -0.04 & & 0.81 & $* * *$ & Italy & 2.8 & 0.01 & & 0.23 & $* * *$ \\
\hline Switzerland & 24.1 & -0.13 & & 1.20 & $* *$ & Switzerland & 13.7 & -0.09 & & 0.64 & $* *$ \\
\hline Greece & 20.7 & -0.43 & $* * *$ & -0.04 & & Greece & 7.5 & -0.19 & $* * *$ & 0.19 & \\
\hline Japan & 54.5 & -0.60 & $* * *$ & 1.22 & $* * *$ & Japan & 27.1 & -0.22 & $* * *$ & 1.13 & $* * *$ \\
\hline Average & 16.4 & 0.20 & & 0.43 & & Average & 7.3 & 0.22 & & 0.32 & \\
\hline
\end{tabular}

Notes: The estimation equation for each country is: $L=\alpha+\beta(y-1994)+\delta(y-2007)$, where $y$ is the calendar year, $L_{y}$ is the labor force participation rate in year $y, \beta$ is the coefficient on calendar year, and $\delta$ is the deviation in the time trend effect after 2007. Estimates were obtained using data for 1994-2012. Asterisks indicate statistical significance under a two-tailed t-test ( $* * *$ indicates $P<0.01, * *$ indicates $P<0.05$, and * indicates $P<0.10$ ). Countries are ranked by the rate of participation-rate gain through 2007 . 


\section{Appendix Table A3. Regression Estimates of Labor Force Participation Trends before and after 2007 in Nineteen OECD Countries: Men and Women Aged 70-74}

\begin{tabular}{|c|c|c|c|c|c|c|c|c|c|c|c|}
\hline \multicolumn{6}{|c|}{$\begin{array}{l}\text { Dependent variable: } \\
\text { Labor force participation rate of } 70-74 \text { year-old men in the } \\
\text { indicated country, 1994-2012 }\end{array}$} & \multicolumn{6}{|c|}{$\begin{array}{l}\text { Dependent variable: } \\
\text { Labor force participation rate of } 70-74 \text { year-old women in } \\
\text { the indicated country, } 1994-2012\end{array}$} \\
\hline \multirow{2}{*}{ Country } & \multirow{2}{*}{ Constant } & \multicolumn{2}{|c|}{ Trend } & \multicolumn{2}{|c|}{ Post-2007 Trend } & \multirow{2}{*}{$\begin{array}{l}\text { Country } \\
\text { Portugal }\end{array}$} & \multirow{2}{*}{ Constant } & \multicolumn{2}{|c|}{ Trend } & \multicolumn{2}{|c|}{ Post-2007 Trend } \\
\hline & & 0.45 & $* * *$ & -1.22 & $* * *$ & & & 0.48 & $* * *$ & -1.55 & $* * *$ \\
\hline United States & 15.7 & 0.40 & $* * *$ & 0.23 & & United States & 8.0 & 0.42 & $* * *$ & -0.03 & \\
\hline Netherlands & 3.9 & 0.29 & $* * *$ & 0.13 & & Japan & 13.1 & 0.21 & & 0.66 & \\
\hline Finland & 3.0 & 0.21 & $* * *$ & 0.23 & & Norway & 1.9 & 0.18 & $* * *$ & -0.05 & \\
\hline Canada & 8.2 & 0.19 & $* * *$ & 1.03 & $* * *$ & United Kingdom & 2.5 & 0.13 & $* * *$ & 0.23 & $* *$ \\
\hline United Kingdom & 5.9 & 0.17 & $* * *$ & 0.39 & $* *$ & Canada & 2.6 & 0.12 & $* * *$ & 0.57 & $* * *$ \\
\hline Denmark & 7.0 & 0.16 & $* *$ & 0.01 & & Denmark & 1.3 & 0.10 & & 0.07 & \\
\hline Norway & 5.7 & 0.15 & $*$ & 0.55 & $*$ & Netherlands & 0.9 & 0.10 & $* * *$ & 0.19 & \\
\hline Belgium & 1.9 & 0.08 & $*$ & -0.02 & & Finland & 0.7 & 0.08 & $* * *$ & 0.15 & \\
\hline Austria & 4.4 & 0.06 & & 0.71 & $* *$ & Austria & 1.9 & 0.06 & & 0.32 & $*$ \\
\hline Germany & 3.7 & 0.03 & & 0.50 & $* * *$ & Ireland & 2.7 & 0.04 & & 0.10 & \\
\hline Italy & 4.9 & 0.03 & & 0.15 & & France & 0.3 & 0.04 & & 0.02 & \\
\hline Spain & 1.8 & 0.02 & & -0.02 & & Belgium & 0.4 & 0.03 & & 0.06 & \\
\hline Japan & 29.7 & 0.01 & & 0.18 & & Germany & 1.6 & 0.02 & & 0.29 & $* * *$ \\
\hline Sweden & 10.1 & -0.03 & & 0.25 & & Spain & 0.8 & 0.00 & & 0.08 & \\
\hline France & 2.2 & -0.05 & $* * *$ & 0.22 & $* * *$ & Sweden & 2.7 & 0.00 & & 0.53 & $* *$ \\
\hline Ireland & 15.4 & -0.14 & $* *$ & 0.08 & & Italy & 1.5 & -0.02 & $*$ & 0.04 & \\
\hline Greece & 8.9 & -0.27 & $* * *$ & 0.08 & & Greece & 3.2 & -0.15 & $* * *$ & 0.19 & $*$ \\
\hline Switzerland & 17.2 & -0.35 & $* * *$ & 0.92 & $* * *$ & Switzerland & 7.0 & -0.16 & $* * *$ & 0.54 & $* *$ \\
\hline Average & 9.0 & 0.07 & & 0.23 & & Average & 3.3 & 0.09 & & 0.13 & \\
\hline
\end{tabular}

Notes: The estimation equation for each country is: $L=\alpha+\beta(y-1994)+\delta(y-2007)$, where $y$ is the calendar year, $L_{y}$ is the labor force participation rate in year $y, \beta$ is the coefficient on calendar year, and $\delta$ is the deviation in the time trend effect after 2007. Estimates were obtained using data for 19942012. Asterisks indicate statistical significance under a two-tailed t-test (*** indicates $P<0.01$, ** indicates $P<0.05$, and $*$ indicates $P<0.10$ ). Countries are ranked by the rate of participation-rate gain through 2007. 
Figure A1. Employment-Population Ratios among Prime-age and 60-64 Year-old Adults in OECD Countries, 1989 and 2012

Employment rate of population age 25-54

$(\%)$

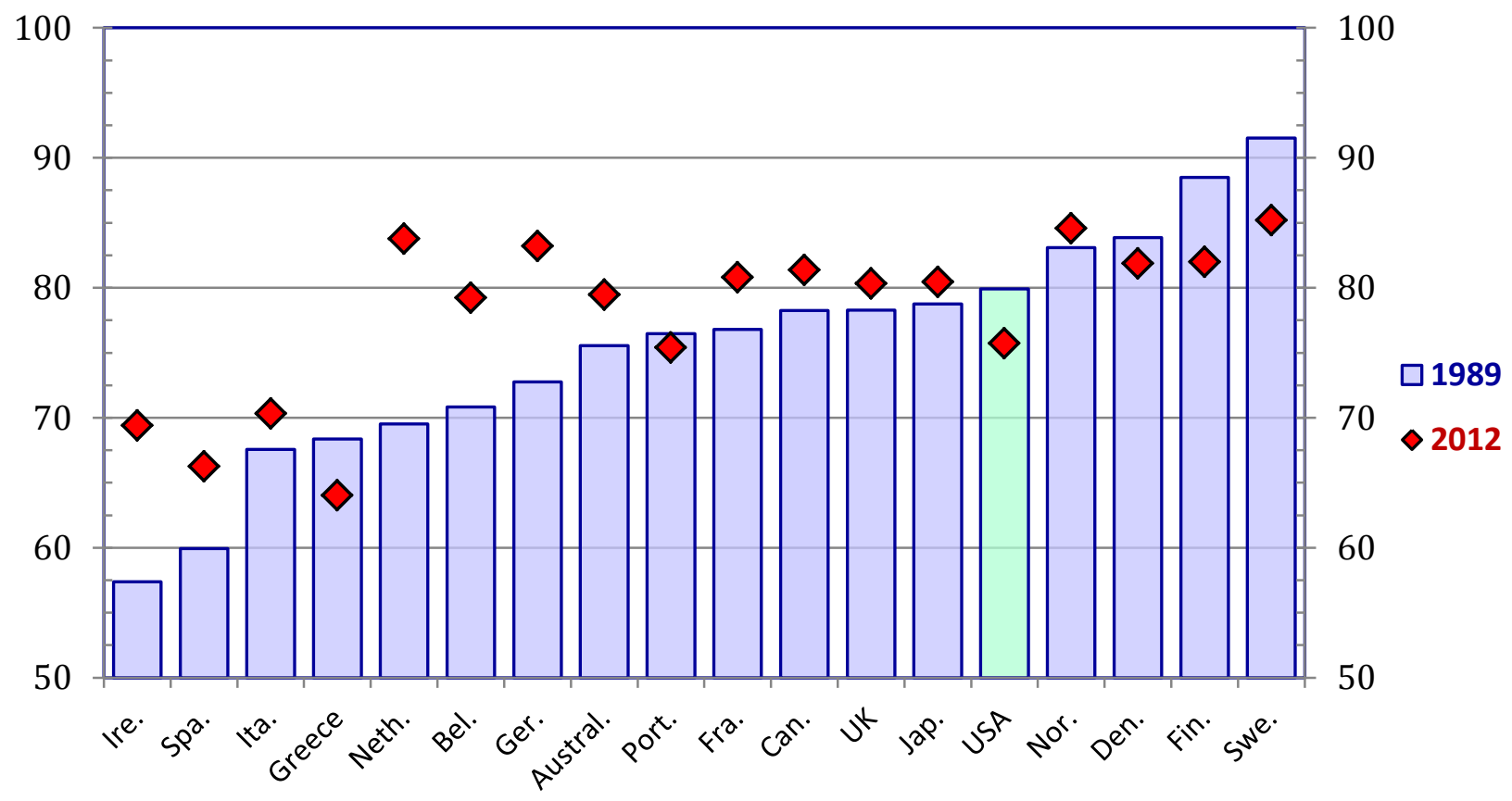

Employment rate of population age 60-64

$(\%)$

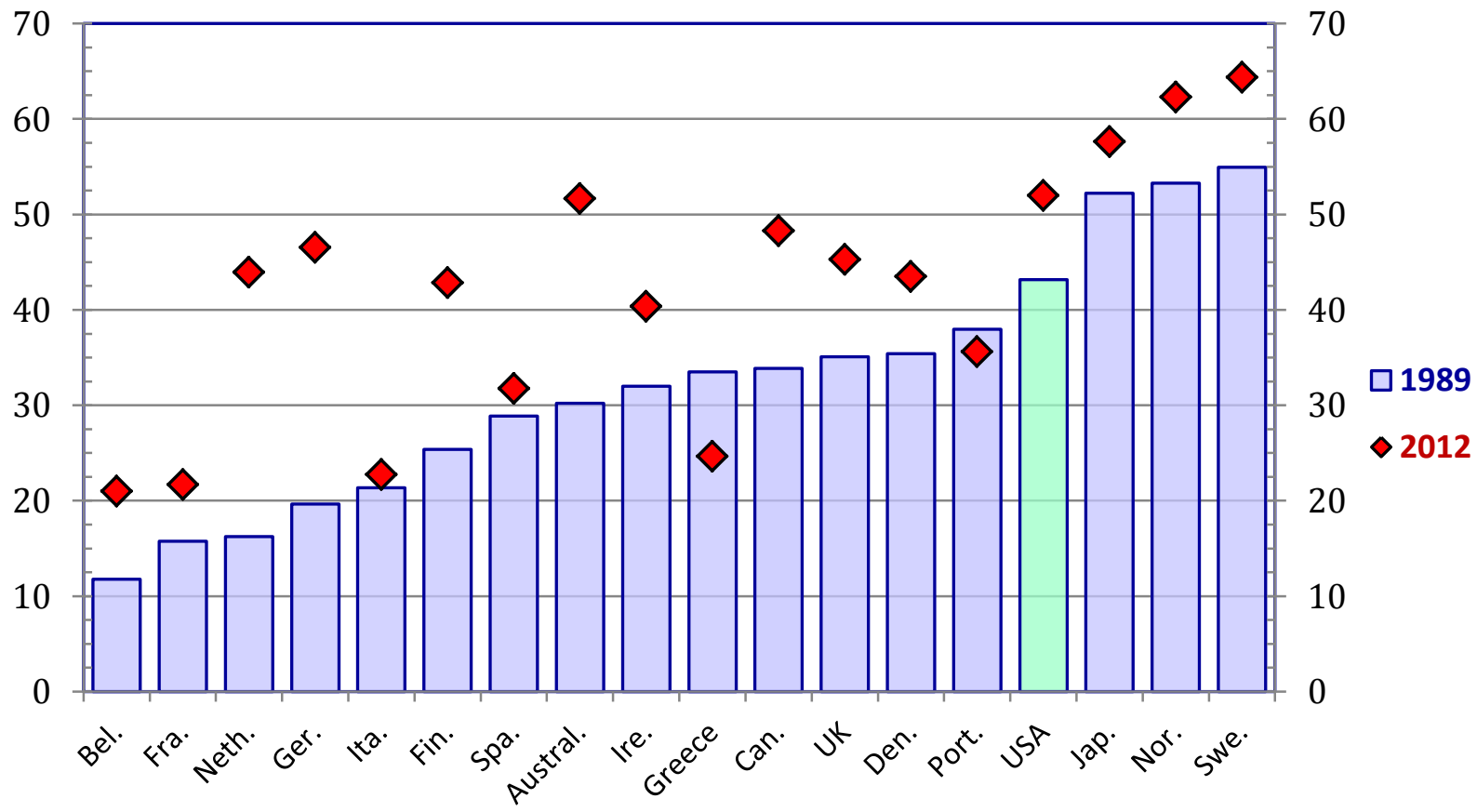

Source: Authors' tabulations of OECD and Eurostat labor force statistics as explained in text. 
Figure A2. Employment-Population Ratios among 65-69 and 70-74

Year-old Adults in OECD Countries, 1989 and 2012

Employment rate of population age 65-69

(\%)



Employment rate of population age 70-74

(\%)

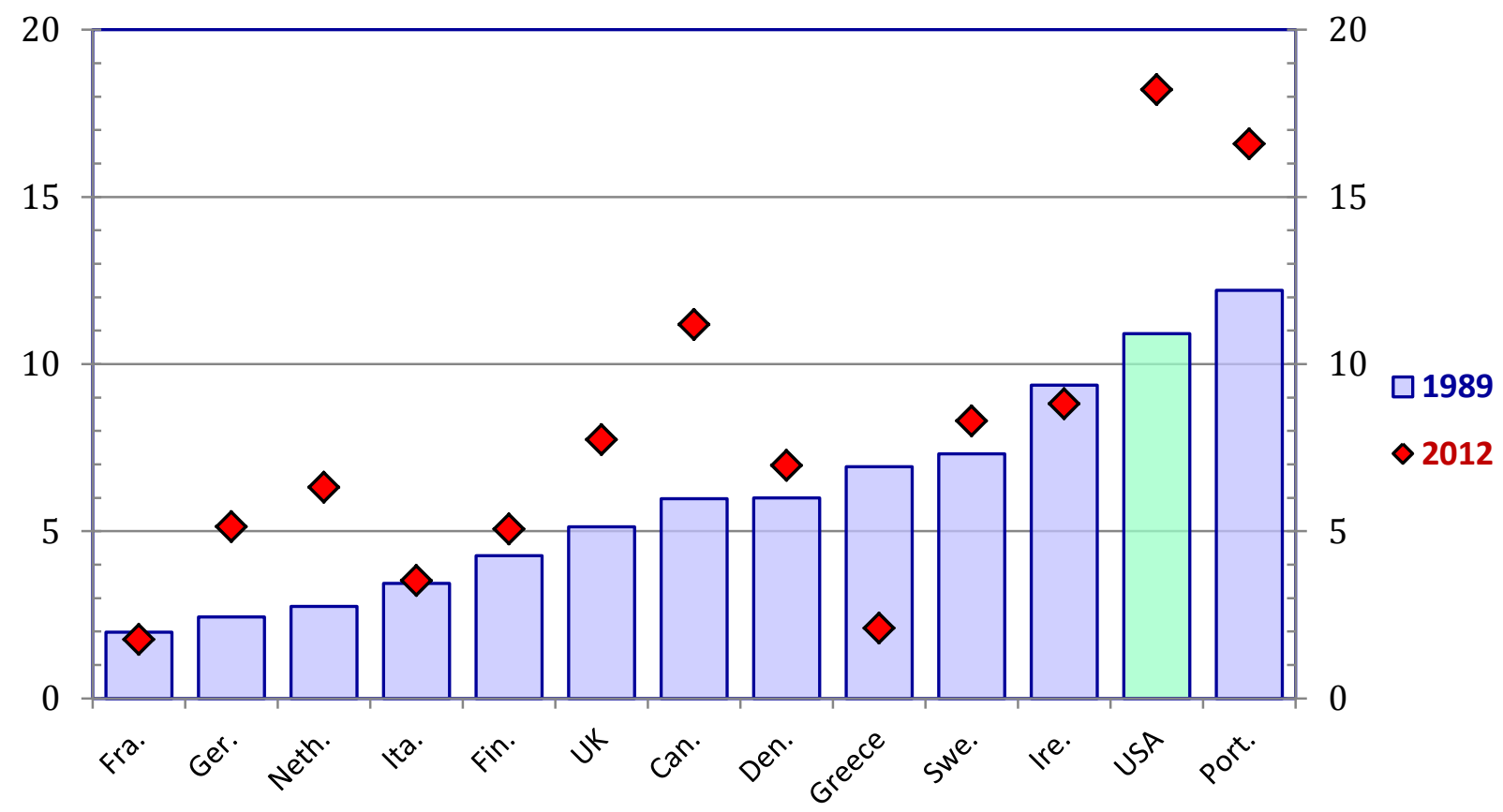

Source: Authors' tabulations of OECD and Eurostat labor force statistics as explained in text. 